Florida International University

FIU Digital Commons

$3-18-2020$

\title{
Elementary School Children's Perspective of Interactive Activities in English Class in China
}

Yaqing Yu

Art, Science \& Education, yyu023@fiu.edu

Follow this and additional works at: https://digitalcommons.fiu.edu/etd

Part of the Bilingual, Multilingual, and Multicultural Education Commons

\section{Recommended Citation}

Yu, Yaqing, "Elementary School Children's Perspective of Interactive Activities in English Class in China" (2020). FIU Electronic Theses and Dissertations. 4374.

https://digitalcommons.fiu.edu/etd/4374

This work is brought to you for free and open access by the University Graduate School at FIU Digital Commons. It has been accepted for inclusion in FIU Electronic Theses and Dissertations by an authorized administrator of FIU Digital Commons. For more information, please contact dcc@fiu.edu. 


\title{
FLORIDA INTERNATIONAL UNIVERSITY
}

Miami, Florida

\section{ELEMENTARY SCHOOL CHILDREN'S PERSPECTIVE OF INTERACTIVE ACTIVITIES IN ENGLISH CLASS IN CHINA}

\author{
A thesis submitted in partial fulfillment of \\ the requirements for the degree of \\ MASTER OF SCIENCE \\ in \\ FOREIGN LANGUAGE EDUACTION \\ by \\ Yaqing $\mathrm{Yu}$
}




\section{To: Dean Michael Heithaus}

College of Arts, Sciences and Education

This thesis, written by Yaqing Yu, and entitled Elementary School Children's Perspective of Interactive Activities in English Class in China, having been approved in respect to style and intellectual content, is referred to you for judgment.

We have read this thesis and recommend that it be approved.

Aixa Pérez-Prado

Ryan Pontier

Eric Dwyer, Major Professor

Date of Defense: March 18, 2020

The thesis of Yaqing Yu is approved.

Dean Michael Heithaus

College of Arts, Sciences and Education

Andrés G. Gil

Vice President for Research and Economic Development and Dean of the University Graduate School

Florida International University, 2020 


\title{
ABSTRACT OF THE THESIS \\ ELEMENTARY SCHOOL CHILDREN'S PERSPECTIVE OF INTERACTIVE ACTIVITIES IN ENGLISH CLASS IN CHINA
}

\author{
by \\ Yaqing $\mathrm{Yu}$
}

Florida International University, 2020

Miami, Florida

\section{Professor Eric Dwyer, Major Professor}

Much research regarding implementation of interactive English activities in Chinese elementary schools has been conducted. Missing, however, are studies from children's perspectives. To garner an initial look into young Chinese students' perspectives regarding English learning, a 41-question survey was conducted to investigate their perceptions of interactive activities.

Sixty-seven participants ( 30 boys and 37 girls) between ages nine and twelve were included. Results showed that $88 \%$ of these students want interactive activities because they can learn happily, and 79\% reported that the interactive activity help improve their test scores. Indeed, most students agreed that interactive activities enhance relationships among students, teachers, and parents. However, 19\% of the students complained that interactive activities are a waste of time.

Overall, students mostly lauded interactive activity but with caveats, namely one of a learning curve. Indeed, Chinese students may appreciate interactive learning, but many students may require years adapting themselves to such in-class structure. 


\section{TABLE OF CONTENTS}

CHAPTER

PAGE

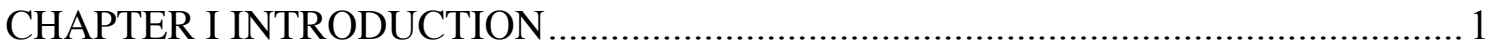

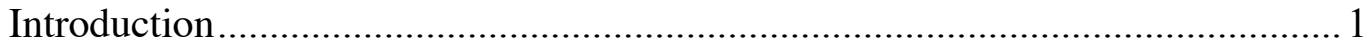

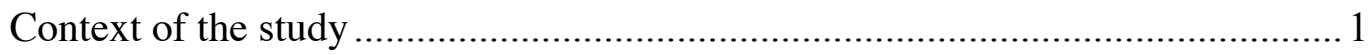

Conceptual framework ............................................................................ 4

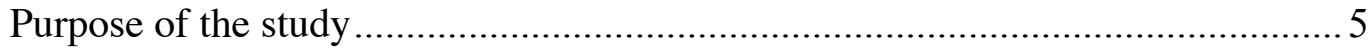

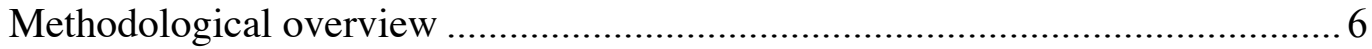

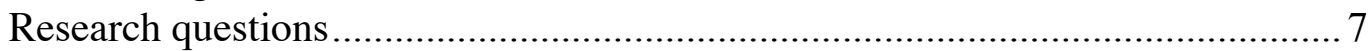

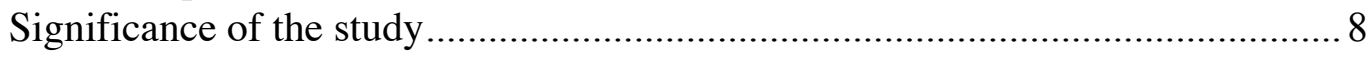

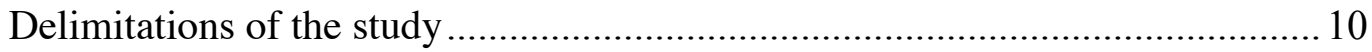

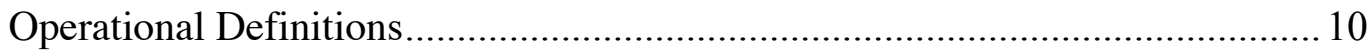

CHAPTER II LITERATURE REVIEW ............................................................. 12

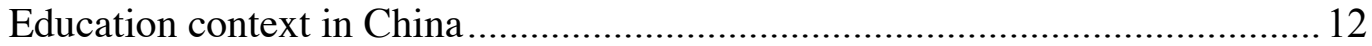

Evidence of student boredom (lack of engagement)....................................... 13

English as a foreign language in Chinese Elementary school contexts .............. 13

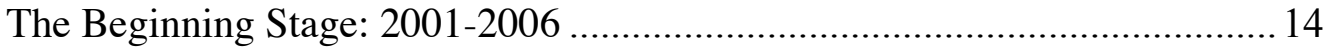

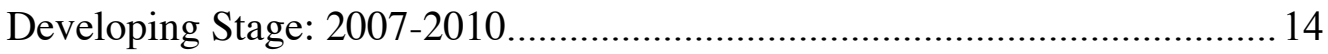

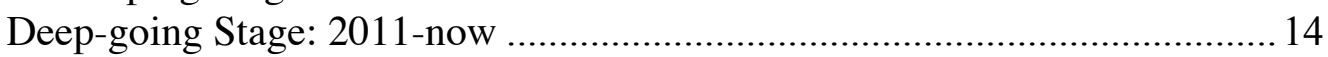

New Basic Education Project.................................................................... 15

EFL teaching and learning activities in Chinese elementary school .................. 16

Conceptual framework ......................................................................... 17

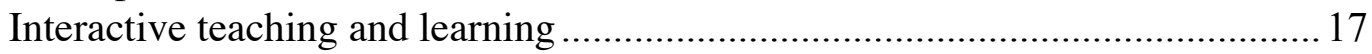

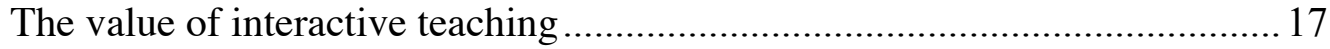

The principle of interactive teaching ........................................................ 18

Communicative language teaching ............................................................. 21

Communicative activities and balancing class time ................................. 22

Instruction: Communicative Approach \& Grammar Translation Method....... 24

Communicative language teaching in China ............................................... 25

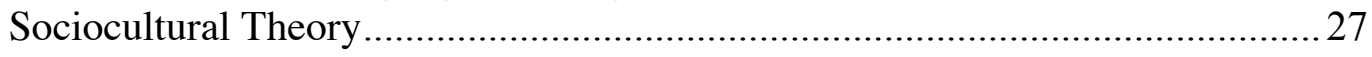

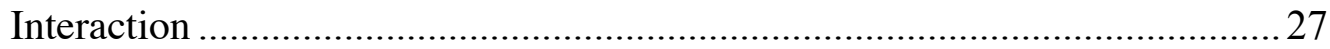

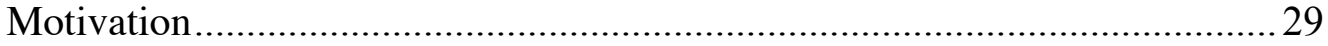

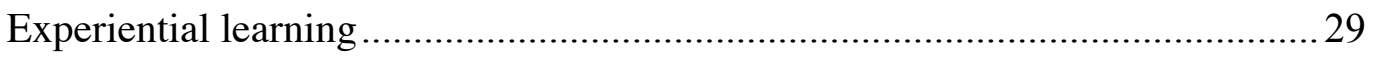

Comprehensible Input, and the Comprehensible Output Hypothesis .................. 31

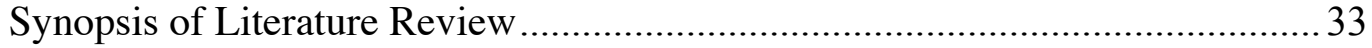




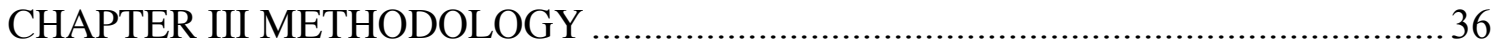

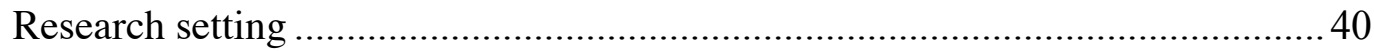

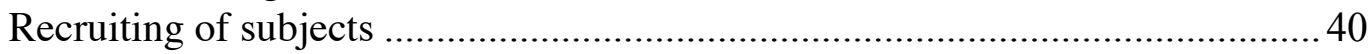

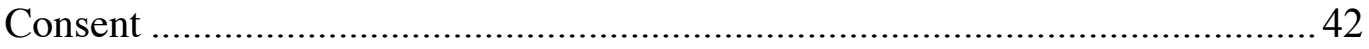

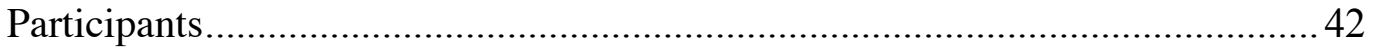

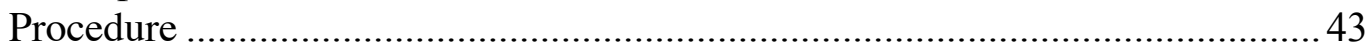

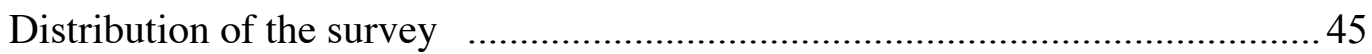

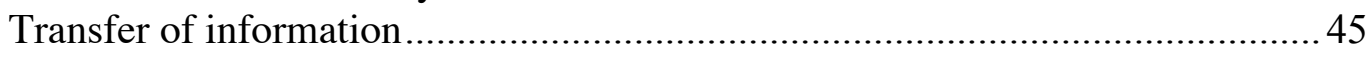

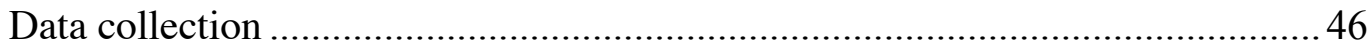

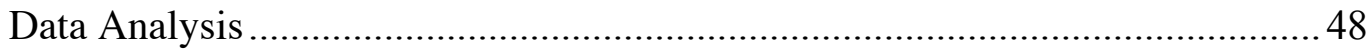

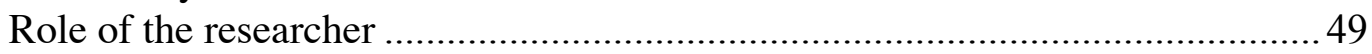

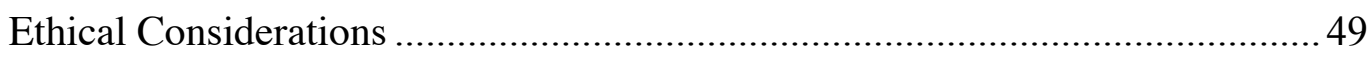

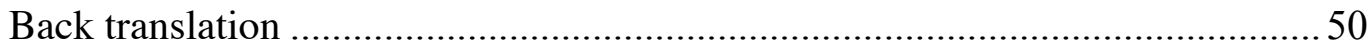

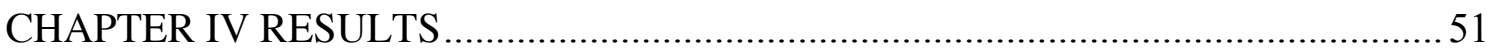

What does interactive teaching mean to elementary aged Chinese students when studying English? ................................................................... 52

What are some attitudes from different age/gender groups regarding

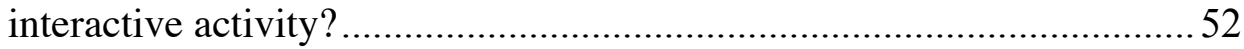

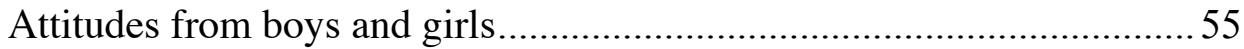

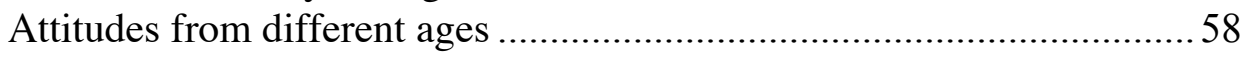

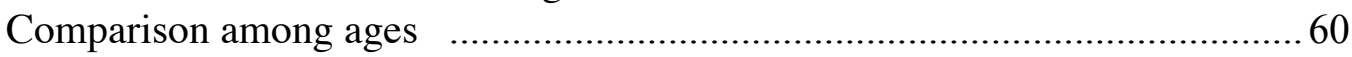

What, from elementary school students' perspective, might be the best teaching form in interactive activity to associate students' learning? .......61

What types of instruction seem to be more acceptable for elementary school students when implementing interactive activities................................................ 62

To what extent do Chinese teachers handle problems and give revision

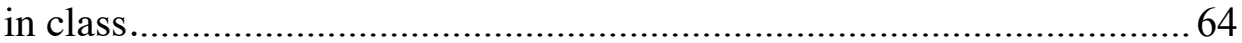

What is the influence of interactive teaching in EFL classes in the development of elementary aged Chinese students, both academically and socially?

To what extent are students and teachers satisfied with

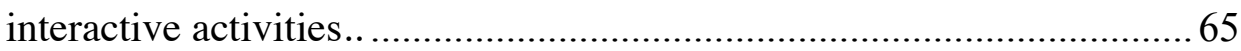

How might interactive activities help students improve scores on traditional English tests? 67

To what extent might interactive activities help raise students' learning ability and confidence, and assist in their motivation 


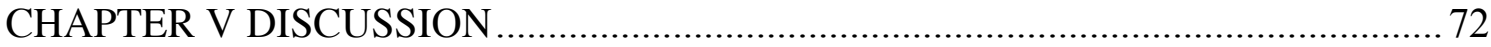

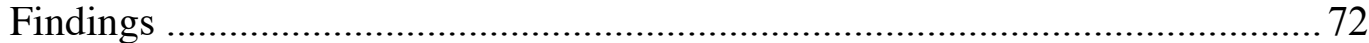

Attitudes from different age \& genders .................................................... 72

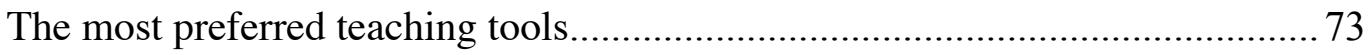

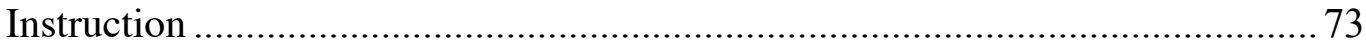

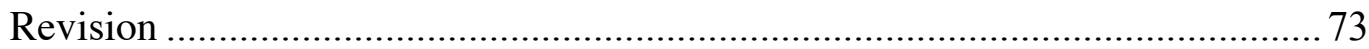

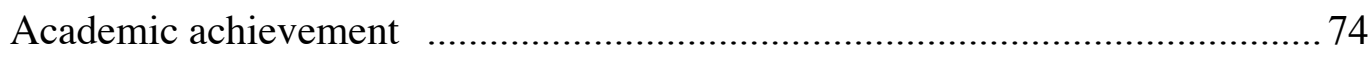

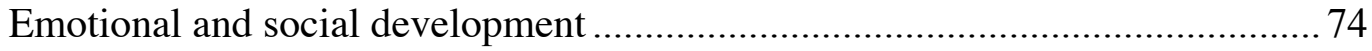

Limitation and implications for further research ......................................... 75

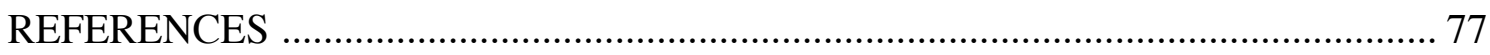

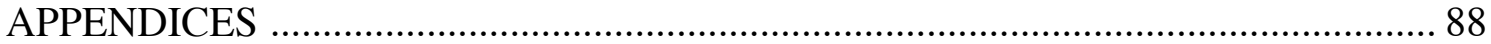




\section{LIST OF TABLES}

TABLE

PAGE

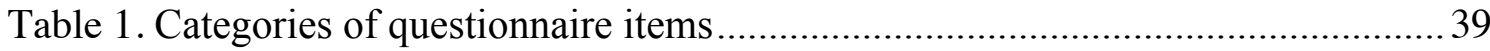

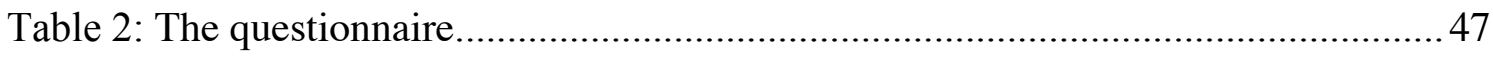

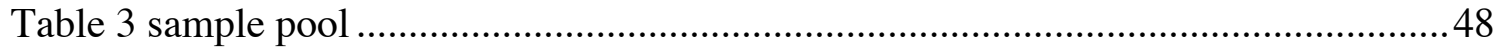

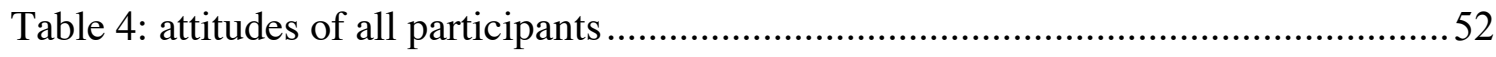

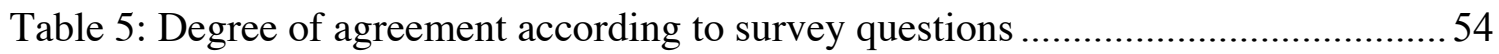

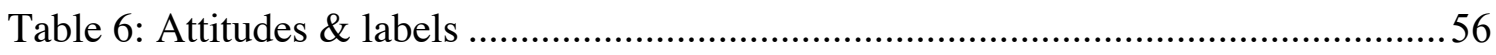

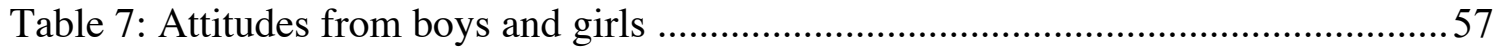

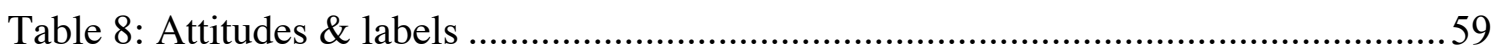

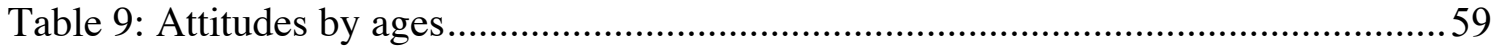

Table 10: Participants' perspective towards teaching tools ...................................... 61

Table 11: Degree of agreement according to survey questions-part 2......................... 61

Table 12: Participants' perspectives towards teachers' instruction .............................. 62

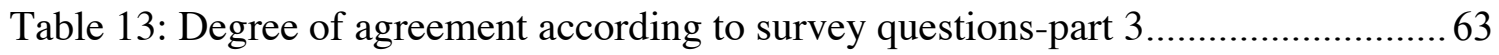

Table 14: Participants' perspective towards teachers' revision................................... 64

Table 15: Teachers and participants' satisfaction of interactive activities .................... 65

Table 16: Degree of agreement according to survey questions-part $4 \ldots \ldots \ldots \ldots \ldots \ldots \ldots \ldots \ldots . . . . . . . . . . .66$

Table 17: Participants' evaluation of their performance in traditional tests ................... 67

Table 18: Participants' perspective of self-improvement from interactive activities ...... 70

Table 19: Degree of agreement according to survey questions-part 5.......................... 71 


\section{CHAPTER I}

\section{INTRODUCTION}

Activity can be a key in improving students' communicative skills of second language study in elementary school. Interactive activity has been found to be a gateway toward transferring children's vigorous energy into knowledge (NRC, 2000), where transferring is often considered a hallmark of true learning (Barnett \& Ceci, 2002). Considerable research (for example, Brown, 2007 and Xia, 2015) has examined effective activities in English as a Foreign Language (EFL) teaching and learning. A broad range of research (for example, Li 2015; Xia \& Xia \& Li, 2012; Rui \& Chew, 2013) has been conducted with respect to implementation of ESL activities in Chinese elementary schools. Missing, however, are studies from children's perspectives regarding these interactive activities.

\section{Context of the study}

Established in 1949 and developed over 70 years, the People's Republic of China now embraces the largest education system in the world. There are almost 260 million students and over 15 million teachers in over half a million schools in China (National Bureau of Statistics of China, 2014), not including graduate education institutions.

China's education system is not only immense but diverse (OECD, 2016).

Education is state-run, with little involvement of private providers in the school sector, and increasingly decentralized. Students in China are required to complete nine years of compulsory education (elementary school and junior high school). Elementary education 
starts at age six for most children and the majority of the students spend six years in elementary school, then they spend another three years in middle school.

To emphasize the compulsory nature of elementary schools, and as a part of the effort to orient education away from examination performance and towards a more holistic approach to learning, the government has replaced the entrance examination with a policy of mandatory enrollment determined by the area of residence (OECD, 2016, p. 10). According to The Basic Education Curriculum Reform Outline (Ministry of Education, 2001), the primary school curriculum should consist of courses that encourage all-around development of individual learners. The reform document suggests that schools offer courses like morality and life, Chinese, mathematics, physical education, and art to elementary students in lower grades. Morality and society, Chinese, mathematics, science, foreign language, comprehensive practical activity, physical education, and art should be offered to elementary students in higher grades. Within these requirements, most schools in China provide English curriculum in third grade.

Throughout elementary education, comprehensive practical subjects are also looked up as compulsory subjects: social and natural investigation, social service, design and production, company visiting and experience all belong to the comprehensive practical curriculum (Liu, 2017). These subjects are aimed at improving students' creativity and research capability, as well as helping students develop a sense of social responsibility through practical experiences (OECD, 2016, p. 24).

The goal of Chinese Ministry of Education promotes an ideal of testing with respect to placement into leveled schools. Junior high school entrance tests force elementary school students to study with the goal of achieving high test scores, which 
means they have overload homework and after school assignments to be able them to enter the junior high school on time (OECD, 2016). Most Chinese elementary school classrooms maintain a capacity of around 50 students, and each class session is 45 minutes. Still, the Chinese Ministry of Education encourages teachers to implement classroom activity to help students' academic and social development (Ministry of Education, 2001). However, given large enrollments, limited class time, and test-based curricular objectives, many teachers find the thought of in-class activity as a challenging practice to promote their classroom as a fun and knowledgeable place for learners to immerse (OECD, 2016).

Fundamentally, Chinese education is a government-ruled institution. Naturally, many Chinese parents have realized limitation in public school education, so they engage their children into diverse afterschool programs with the goals of first passing the school entrance test and then becoming more intelligent and competitive (OECD, 2016).

With this context in mind, I conducted my research in a tier two city ${ }^{1}$ named Xuzhou in Jiangsu province, a relatively educationally advanced area in China, where education policy should be strictly implemented (Ministry of Education of People's Republic of China, 2015). I chose three educational institutes with afterschool English programs to make sure the majority of the students are from different elementary schools and have experienced interactive activity in English learning. The student sample for this study came from the third grade to sixth grade where students' age range is from nine to

\footnotetext{
1 The Chinese city tier system is a hierarchical classification of Chinese cities. It contains 338 cities ranked on 6 tiers: tier 1 , new tier 1 , tier 2 , tier 3 , tier 4 , and tier 5 . It is often referred to publicly when describing communities involved in commerce, transportation, tourism, and education. (Hinsdale, 2017; Ming 2017).
} 
twelve years old, since beginning children's English is taught to such children in Chinese elementary schools.

\section{Conceptual framework}

Interactive activity is a teaching strategy that formed in the teaching process through the interaction between the teacher and learners. The conceptual framework for the present research, as expressed in Figure 1, is a combination of pedagogical considerations of interactive teaching and learning including Communicative Language Teaching, Sociocultural Theory, Experiential Learning, Comprehensible Input, and the Comprehensible Output Hypothesis (COH).

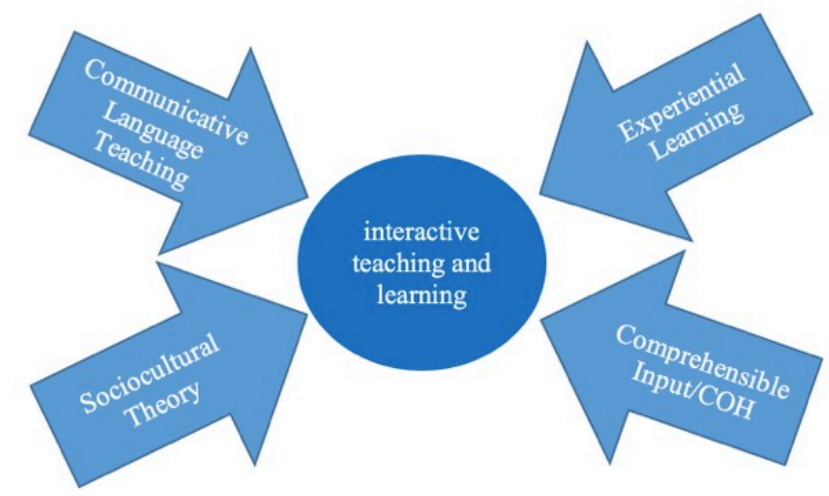

Figure 1. Conceptual Framework of interacting teaching and learning

The communicative teaching method is also called the interactive teaching method (Senthamarai, 2018), as communication requires interaction. Sociocultural theory emphasizes roles in the development of cooperative dialogues between children and more knowledgeable members of society. Giorgdze and Dgebaudze (2017) observe that interacting in community is the most common way children develop their learning. Gentry (1990) claimed that experiential learning is participative, interactive, and applied, 
emphasizing that learners acquire knowledge by doing where young students learn by playing. The comprehensible input hypothesis, or $i+1$, indicates that new language delivered to learners should be intelligible to them without discouraging them from understanding it, even if there is just a little bit of language that have not been learned (Krashen, 1981). Meanwhile, the Comprehensible Output Hypothesis (COH) states that we acquire language when we attempt to transmit a message but failed and we have to try do it again (Krashen, 1998). In order to have comprehensible input and output, which is regarded as the key of language development to interlocutors (Hatch, 1978; Long, 1983; Iwashita, 2001), modified interaction can be required.

In sum, interaction appears inseparable between communicative approaches and experiential learning; thus, interaction may be seen as a critical element in sociocultural theory, as well as considerations of Krashen's comprehensible input and output hypothesis.

When EFL teachers apply a combination of these approaches and theories, interactive teaching and learning is a reasonable and likely output that transcends many teaching approaches.

\section{Purpose of the study}

In an attempt to satisfy the educational goal of the New Basic Education Project $(\mathrm{NBEP})^{2}$ in China to achieve children's holistic development, how teachers arrange

\footnotetext{
2 The NBEP is a large-scale and long-term education reform project, and has been conducted by principals, teachers and professors since 1994 (Ye, 2006; Bu \& Li, 2013). It values students' active involvement in schooling, and respects the potential of teachers' professional development. The project sheds light on the collaboration between elementary educators and university professors, and focuses on innovative practice to improve schooling (Gu, Yin, and Li, 2015).
} 
teaching time reasonably, design classroom teaching, and carry out interactive activities in the classroom to help students' academic and social emotional development remains to be verified, I designed a questionnaire to see, at least from the perspective of elementary students, how the implementation of classroom interactive activities in Chinese primary schools affect them.

\section{Methodological overview}

In 2015, Gu, Yin, and Li studied students' responses to homework in China. More importantly, they examined a concept called happy homework, which refers to fun and easy school assignments, which conceptually might advance relationships among students, teachers, and parents. A further objective of the research was to take such homework and examine it with respect to students' emotional and social development. According to Gu, Yin, and Li, all parties — students, families, and teachers - were nearly unaminously pleased by having happy homework as a regular feature of their young students' school lives. The findings of their survey seemingly apply to the conceptual framework envisioned for this research in that it relates to NBEP goals.

Gu et al. (2015) examined students' understanding includes their value, participation, collaboration, and attitudes toward homework's content, assessment, and revision. They also noted that the concept of achievement consists of general assessment, class culture, relationship of teachers, parents and students, particularly with respect to academic and social development. However, for this thesis, since it is an examination of interactive activities, the class culture, teaching content, collaboration among teacher, parents and students were not discussed. Instead the concepts of teacher's instruction, 
teaching material, students' motivation and the media with which interactive activities are yielded were included. Because from the conceptual framework of the thesis we know that communicative approach, experiential learning, and comprehensive input and output hypothesis all emphasize the important role of instruction, teaching material plays in interactive teaching and learning (Sowell, 2017; Salaberri, 1995; Huynh, 2017; Mulling, 1997; Prozesky, 2000), and as an inseparable element in social culture theory (Vygotsky,1987), motivation of the students to participant in interactive activities was also assessed in this study.

\section{Research questions}

In order to garner an initial look into young Chinese students' own perspectives regarding their English learning, namely with respect to their notions of enjoyable interactive activities, a survey was conducted to investigate students' in-depth understanding of these activities. Students' attitude, motivation, value, participation and learning outcomes of interactive activities were principal concerns of the present investigation. The study focused on influences of interactive activities with respect to students' second language learning and social development. The investigation was conducted by pursuing the following two research questions and their corresponding subsidiary questions:

1. What does interactive teaching mean to elementary aged Chinese students when studying English?

a. What may be some different attitudes from different age/gender groups with respect to interactive activity? 
b. What might be some important elements in interactive activity from elementary school students' perspective?

c. What types of instruction seem to be more acceptable for elementary school students when implementing interactive activities?

d. How might revision and feedback from teachers help students' English learning?

2. What is the effect of interactive teaching in EFL classes on the development of elementary aged Chinese students, both academically and socially?

a. How might interactive activity help students improve scores in traditional English tests?

b. How might interactive activity help raise students' learning ability and confidence, and assist in their motivation?

\section{Significance of the study}

Learning activities should benefit students' holistic development (Ye, 2006; Bu \& Li, 2013). As students are the center of the teaching and learning activities (Ye, 2006), students' voices should be heard. This study should explore students' value and recognition of ESL interactive activity under the background of Chinese education and uncover the effectiveness of implementing interactive activity to associate students' English learning in the context of NBE (The New Basic Education, 1994). It was hoped that the research might find that degrees to which interactive activity may improve students' performance of English learning and affect students' social emotional development such as promoting students' self-awareness and communicative skills. 
Another key objective was to uncover results which could contribute to guiding English teachers in China in the instruction and design of EFL activities by understanding students' learning needs, in an effort to provide high quality classroom teaching promoting students' English acquisition.

Language education worldwide has uncovered that interactive learning may speed up learning new languages for many people. However, traditional Chinese in-class presentation includes teacher-centered learning (Zhang, 2012). While coaches allow players to play in order to learn a game - they don't play the games for them-while orchestra directors help facilitate accurate and expressive music from the musicians in the symphony - they don't play all the instruments at the same time, language teachers in East Asia often do all the talking while the students sit and watch their teacher speak and write (Lee,2011). Recently, in China, the concept of student-centered language learning has taken a little root and colleagues are examining the cultural phenomena experienced by both teachers and students (LunWenData, 2018), which is however quite new in China. Furthermore, to our knowledge, no one has really asked young learners what they think of their English learning with respect to interactive activities_-at least not in China. Thus, these answers are likely some of the first we are to experience regarding interactive language learning experiences from really any young person studying English in China, especially given the new learning contexts being attempted.

If research shows that students may engage more fully in interactive language learning, we may see children learning English far more quickly than they have been up to this point in China. And even if research indicates that they are, the English teaching profession in China may benefit by knowing if children find interactive language learning 
a positive experience or not. If students hate the interactive activity, teachers might drop it or severely adjust based on student feedback. If students love it, and teachers are later able to couple students' positive experiences with positive outcomes, then the profession can understand that interactive language teaching offers promising prospects for asserting reform in an educational context in a country of one billion people.

\section{Delimitations of the study}

The study is examining interactive teaching in general fashion specific approaches to interactive language teaching for example task-based language teaching is not a focal point of the present study.

The study is exclusively using a questionnaire. It is not using pre- and postassessment techniques to see the degree to which proficiency levels are changing as a result of interactive activity. Similarly, the particular study does not employ observational techniques to assert in-class dynamics as they occur.

\section{Operational Definitions}

Within the thesis, the following terms are used. Descriptions unique to these terms are defined here:

EFL - English as a Foreign Language - A traditional term for the use or study of the English language by non-native speakers in countries where English is generally not a local medium of communication (Nordquist, 2017). 
ESL - English as a Second Language - the teaching of English to speakers of other languages who live in a country where English is an official or important language (Cambridge Dictionary, n.d.)

ESOL - English for speakers of other languages - Term is used, especially in the UK, to refer to the teaching of English to students whose first language is not English, but who are living in an English-speaking country (Cambridge Dictionary, n.d.)

ESOL-friendly. Also known as ESOLish, the term indicates that an ESOL class that is interactive, communicative, engaging, and cooperative, where teachers instruct with body language, as well as verbal and visual tools, where the students' high order thinking can be cultivated (Pérez-Prado, 2019).

Happy homework - Homework that students name as easy and fun, that has students achieving tasks at one stroke, and that has children and parents purportedly improving themselves together (Gu Yin and Li, 2015).

Interactive activity - A teaching strategy formed in the teaching process through the interaction between the teacher and learners. Within the existing learning conditions, the learning process is considered as an interaction between the teacher and student, aiming to transfer common knowledge, skills, and values to the student (Giorgdze \& Dgebuadze, 2017). 


\section{CHAPTER II}

\section{LITERATURE REVIEW}

The key objective of this chapter is that readers will have a deep understanding of Chinese education system as well as the English education under the context of a large population. One should also see the foundational elements (principles) in interactive activities, as well as influence of interactive activities both academically and mentally worldwide. Finally, readers are invited to raise the same question that I raise with this study: that with such big influence globally, how interactive activities might be adapted into the Chinese education system, especially when bearing affective considerations of elementary students in mind.

\section{Education context in China}

According to English Curriculum Standards for Compulsory Education revised by the Ministry of Education of the People's Republic of China in 2011, "the unified instrumental and humanistic English curriculum is conducive to laying the foundation for students' lifelong development." However, with the revised English Curriculum Standards for Compulsory Education in 2011, Chinese English teachers have tended to focus more on the students' learning processes, believing that teacher's guiding will directly affect the cultivation and development of students' English thinking ability. (English Curriculum Standards for Compulsory Education, 2011, Ministry of Education of the People's Republic of China). 


\section{Evidence of student boredom (lack of engagement)}

The contemporary Chinese education remains exam-oriented, relying on rote memorization and mechanical drills (Zha, 2015). Examination-oriented education has maintained characteristics such as the utilitarian purpose of education, the uniformity of the teaching content, the spoon-feeding way of teaching, and speculation. Since 1952, education in China has been fully integrated into the national unified plan and become a national behavior. With a national set of textbooks, examination-oriented syllabuses, a highly unified teaching mode, the Chinese education cultivated a large number of talents with unified specifications. This limited teaching content in textbooks and the unified exam syllabus, where violators will be unable to bear the fate of being eliminated ( $\mathrm{Lu}$, Tang, \& Luo, 2007)

\section{English as a foreign language in Chinese elementary school contexts}

English as a Foreign Language (EFL) studies in China were commonly focused in the field of higher education such as the practice of high school and college students (OECD, 2016). Not until 2001 did the practice and studies of EFL in elementary school start to raise people's attention as the Ministry of Education of China (MEC) announced that English has officially become a compulsory subject in Chinese elementary school (MEC, 2001). There were three stages of EFL in Chinese elementary school, from preliminary discussion of the necessity of set English curriculum in Chinese elementary school to the construction of cooperative and harmonious English classroom, EFL studies in China experienced three periods of its practice in Chinese elementary school (Zhou, 2018). 


\section{The Beginning Stage: 2001-2006}

The earliest stage was a period when scholars in China were discussing whether should Chinese elementary school students learn English at school. In 2001, the Ministry of Education of China issued Actively Promoting the English Courses in Primary Schools to the public to announced the English has become the official curriculum in China, and the relevant studies and discussions in the following five years were focused on issues that raised in English classrooms in Chinese elementary school (Wang 2011 \& Wu, 2011).

\section{Developing Stage: 2007-2010}

A new round of English curriculum reform took place in this stage. Studies about the current situation of English course merges from not only highly populated provinces but also those with extremely remote rural areas (Zheng, Zhou \& Zhang, 2011).

\section{Deep-going Stage: 2011-now}

In the last decade, experts have been focusing on English teaching methods and students' learning strategies during this period of EFL practice. Interactive activities have started to become popular as it is feasible for them to be integrated into English courses in Chinese elementary schools (Xia \& Li, 2012).

From 2011 to now, the EFL practice in Chinese elementary school has generally concentrated on curriculum design, the study of teaching methods and modes, as well as research of teaching subjective and regional education. All the previous aspects are all 
leading towards that English education in China should be student-centered, innovative, and cooperative with diverse adjustable teaching mode (Zhou, 2018).

\section{New Basic Education Project}

My study utilized the New Basic Education Project (NBEP) in China-a largescale and long-term education reform project—conducted by principals, teachers and professors since 1994 (Ye, 2006; Bu \& Li, 2013). The project focused on students' innovative practice, teacher-student interaction, classroom activities, the revision and rebuilding of teaching behaviors, and other issues related to children's holistic development (Li, Wang, \& Chen, 2013; Li 2015; Li, 2006). Those elements challenge traditional Chinese ESL education and require teachers to dominate interactive activities to associate students' English learning. Students' behavior, ways of thinking, the cultivation of the spiritual world, and the learning state are highly valued in NBEP (Li, 2006). The New Basic Education Project also emphasizes the importance of life and regards education as a career that embodies the concern with life in a civilized society (Ye, 2006). Thus, as one of the main foci in promoting students' learning and social skills and developing students' mental health, the implementing of interactive activity in ESL classrooms in China promotes the students' active involvement in schooling and students' ability to adapt the text knowledge to the real world. 


\section{EFL teaching and learning activities in Chinese elementary school}

English education in China is also examination-oriented. The teaching process emphasizes vocabulary and grammar translation, where authentic English language is always ignored (Yu, 2008). In traditional Chinese teaching philosophy (Wang \& Lin, 2018), teachers attach great importance to teaching knowledge to students with the belief of good testing results comes after a large number of exercises. Students may be good at reading and doing the tests, but when communicating with foreigners, they are at a loss or their words fail to express their meaning. As an example, we may look at overt vocabulary instruction. In the past, teachers often used the following two methods $(\mathrm{Yu}$, 2008):

1. When students are in the lower grade stage, they imitate the teacher's pronunciation by listening and reading, but some teachers' pronunciation is not accurate, which may directly mislead students.

2. In the process of senior English teaching, teachers will use phonetic symbols to help students read words out loud. However, these methods can affect test results, and often students forget such details.

One of the interesting phenomena coming from such vocabulary teaching experiences is that students notate English pronunciation by referring to Chinese characters with similar pronunciation, thereby assisting memorizing and pronouncing English words. However, we may wonder whether such practice is ultimately meaningful and effective learning. 


\section{Conceptual framework}

In a nutshell, interactive language teaching has gained enthusiasm in China and eastern Asia in the early part of the $21^{\text {st }}$ century, seemingly after a number of years of resistance to such developments elsewhere in the world. Nguyen (2018) observed that a conceptual framework regarding interactive teaching and learning likely includes notions of Communicative Language Teaching, Sociocultural Theory, Experiential Learning, Comprehensible Input, and the Comprehensible Output Hypothesis, as portrayed in the reprise of Figure 1.

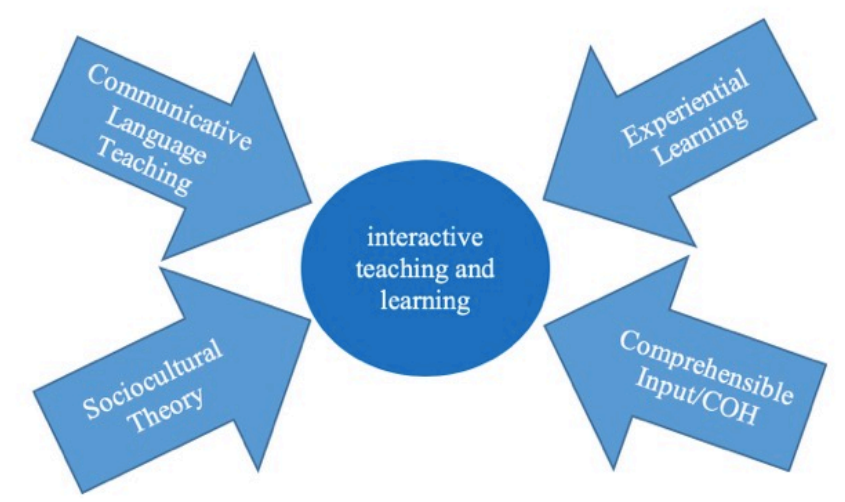

Figure 1 (reprise). Conceptual framework.

\section{Interactive teaching and learning}

\section{The value of interactive teaching}

Interactive activity is a teaching strategy that formed in the teaching process through the interaction between the teacher and learners. Within the existing learning conditions, the learning process is considered as an interaction between the teacher and student, aiming to transfer common knowledge, skills, and values to the student (Giorgdze \& Dgebuadze, 2017). Traditional lecture in courses revealed limited 
effectiveness in learning. However, interactive teaching is now viewed as a new kind of quality educating (Senthamarai, 2018).

Without practical application, students often fail to comprehend the depths of the study material (Room 241 Team, 2017). Very often, they are found not to actually learn the material until asked to make use of it in assessments (Yee, 2019). Successful teachers, at least those whose students demonstrate positive assessment outcomes, are able to engage their students through interactive teaching to have them participate and reach learning goals (Room 241 Team, 2017) Meanwhile, effective teachers develop positive interactions among students, often as a result of training and development of key social personality traits (Senthamarai, 2018). Interactive learning helps learners not only easily acquire new material but also memorize it for a longer period of time (Giorgdze \& Dgebuadze, 2017). The advantages and effectiveness of the interactive methods are to activate creative thinking, analytic and argumentation skills in students. Thus, interactive activity also helps students develop conversation, discussion, team-work, and effective communication skills, as emotional contacts created through interactive learning make students listen to peers.

\section{The principle of interactive teaching}

Above all, using interactive techniques and strategies to get students motivated and engaged in learning, retain information, be creative and satisfied, and confident in communication. Therefore, the students are able to reach a better level of academic, emotional and social development. The principle below provides a guideline to implement interactive activities in class for ESOL teachers. How those principles are 
applied by elementary English teachers will be investigated by a survey in the students' perspective. Nevertheless, authors and programs have expressed interactive teaching as including some critical features:

1. Interactive teaching styles have been shown to

a. Assess student accomplishments. The instructor can easily and quickly assess if students have really mastered the material (and plan to dedicate more time to it, if necessary), and the process of measuring student understanding in many cases is also practice for the material, the very nature of these assessments drives interactivity and brings benefits (Yee, 2019).

b. Motivate students. Two-way teaching dispels student passivity, and when more students are engaged, teacher will have much more fun too (Room 241 Team, 2017). Interactive lessons encourage student participation and active knowledge checking to ensure that key concepts are understood (Algonquin College, n.d.).

c. Use proper instruction. Interactive instruction enhances the learning process (Room 241 Team, 2017). Use of the native language to give instructions might be helpful for beginning-level students, if continued for too long, it becomes a handicap rather than a help (Sowell, 2017).

d. Support students' academic development. Interactive strategies in class allow students to make stronger connections to the course material and minimize time spent in passive listening. When interactive components are well integrated into a lecture, students retain more information, having 
been exposed to different perspectives and critical discussion (Cavanaugh, 2011, p. 1). By implementing these interactive components, students may improve their target language skills.

2. Interactive teaching styles should be

a. Flexible in Revision. Applying training methods that involve two-way communications can enable students to make quick adjustments in processes and approaches. Teachers are encouraged to implement teaching aids that press for answers, while capturing and holding students' attention (ARMA International Center for Education, n.d). In the questionnaire of this thesis, the following contemplations were investigated:

i. Are teachers able to handle the problem occurred in activities? and

ii. Do teachers often give feedback to students to encourage learning?

b. Communicative. Students in the role of a "teacher", Socratic dialogue, asking questions (Giorgdze \& Dgebuadze, 2017). In a communicative approach, each individual contributes to the teaching process, students exchange information and ideas. This relationship allows students not only to acquire knowledge but also to develop communicative skills. The teacher must use dynamic and communicative teaching methods, constitute the basic elements of a recently developed process to motivate learning, so that the students and future engineers develop a critical position about the taught content (Senthamarai, 2018). 
3. Interactive teaching styles should apply teaching tools, both visual and audio,

a. Using visual tools such as maps, diagrams, video and music, and asking students to work in groups or pairs in ESOL-friendly activities friendly (Mulling, 1997), which utilize students' higher order thinking and cooperative learning. These tools may also assist in engaging students into communicative dialogues where authentic language can be acquired (Prozesky, 2000).

Indeed, education experts and leaders are advocating interactive activities in classroom teaching. However, whether the application of interactive activities really improves students' academic level and enhances their emotional and social development remains to be discovered. How can one improve the quality of the product without a customer's survey? Certainly, the detail in these descriptions suggest that many professionals advocate for interactive teaching and learning, but nowhere among these suggestions do we hear feedback from students. Do students feel the interactive activities in China really improve their English academic level and enhance their emotional and social development? Uncovering this lack in the academic lore surrounding interactive activity in China-based language education is a key objective of my investigation.

\section{Communicative language teaching}

Language is created for communication, which encompasses two main functions of interaction and transaction (Brown \& Yule, 1983). Communicative Language Teaching (CLT), perhaps the most significant approach in the late twentieth century, is widely used in EFL classrooms and continues to influence learning and teaching theories 
and methods in the ESL world (McIntosh, 2016). Communicative teaching methods is also called interactive teaching methods (Senthamarai, 2018), "competence in terms of social interaction" is deemed as the priority of this method (Kumaravadivelu, 2006, p. 60). It makes communicative competence the general goal of language learning through integrated teaching of the four language skills (reading, writing, listening and speaking), where a lot of interactive activities would take place for my integration.

Brown (2007) underlines the importance of allowing learners to use authentic language in the class, which they may encounter later in life. Learners are expected to become successful communicators when adequately using language in social contexts. Communication-driven (interactive) activities such as games, role-plays, and problemsolving tasks are composed of three key components: information gap, choice, and feedback. An additional hallmark of the communicative method is the intensive use of authentic materials, which expose students to how language is actually used. These activities have been rigorously used to engage students into the authentic language practice.

\section{Communicative activities and balancing class time}

Communicative language teaching uses real-life situations that necessitate communication, where teachers set up scenes that students are likely to encounter in the real-world (Galloway, 1993). When implementing the communicative approach in classroom, teachers should make the activities as truly communicative as possible (Mulling, 1997). In China, an ask-and-answer activity and role play are the two most commonly used activities under the communicative approach. 
As the time for each English class in China is only 45 minutes, balancing class hours and motivating students to speak as much as possible are main concerns for cultivating communicative students in ESOL classrooms. Watson (2017) introduces tips for ESOL teachers to motivate those silent students to be talkative. The following five items are highlighted because they consider more adaptability in Chinese classrooms and support teachers in handling problems classroom:

1. Do not steal the struggle, give students time and silence to work through struggling.

2. Use non-verbal reinforcement for behavior when necessary. ${ }^{3}$

3. Move from the front of the classroom. Try occasionally sitting on the side of the classroom or in an absent student's desk and say, "I need someone to go up and demonstrate __ for us.” (Watson, 2017, p. 1)

4. Teach students signals for your often-repeated phrases and for transitions.

5. Do not overuse repetition in instruction.

The fifth point is a common mistake that teachers may make to emphasize what they think is important but easily ignored by students. For example, if there is a key grammar point students are required to know, instead of repeating in the instruction, highlighting the key point in different forms (dialogue, games, assessments) helps students acquire a more effective and efficient understanding.

3 One of the historical teaching methods, the Silent Way (Gattegno, 1963), indicates these two concepts. The method emphasizes learner autonomy and active student participation. Silence is used as a principle tool toward achieving this goal. 


\section{Instruction: Communicative Approach \& Grammar Translation Method}

Krashen mentioned in his Monitor Model theory (1977) that the acquisition of language is subconscious and it results from informal and natural communication. However, communication is a complex process. At any stage of the process things may go wrong, making the communication less effective (Hubley, 1993). Same arguments in the SLA field about how target language should be instructed are raised by the teachers. Instruction-giving has a direct effect on learning; a lesson or activity becomes chaotic and fails when students do not understand what they are supposed to do (Sowell, 2017, p. 10).

Opinions differ as to whether instruction-giving is a permissible use of the first language (L1) in the second-language (L2) classroom. Atkinson (1987), Auerbach (1993), and Macaro (1997) agree that instruction-giving is an occasion that warrants use of the L1 in the L2 classroom. Both Ur (1996) and Cook (2016) believe that some use of the mother tongue might be necessary. Salaberri (1995) and Gardner and Gardner (2000) assert that students should be introduced to the use of English from the first class (Sowell, 2017, p. 11).

Foreign languages are not just subjects to be studied but are also a means of communication, teachers should strive to incorporate the L2 needed for instruction-giving right from the beginning of a course (Salaberri, 1995). Teacher also should be thoughtful when choosing language in instruction. Use of the native language to give instructions might be helpful for beginning-level students, if it lasts for too long, it becomes a handicap rather than a help. Therefore, teachers should instruct simply and clearly, model the instructions, and use extra-linguistic devices to aid meanings. Extra-linguistic devices - gestures, facial expressions, voice, and visuals are the most important tools that facilitate students' understanding of the instructions (Sowell, 2017). 
Stevie (2018) suggested that the Natural Approach, Audiolingual Approach and Communicative Approach were purposely made strong where the grammar-translation method was weakest. However, using the language that students can understand does produce the efficiency. One may never doubt that authentic target language should be used as much as possible in classroom teaching; nevertheless, recent study regarding translanguaging (Sowell, 2017) note that use of some students' mother language may be helpful when students are confused about the instruction and start to feel distracted. However, situations vary depending on the language used in teaching. If the students are from the same culture background and all speak the same first language, there won't be a problem when applying their first language in classroom teaching. On the other hand, if a class occurs in a multicultural site, choosing the medium of instruction may result in more anxiety and confusion.

\section{Communicative language teaching in China}

Communicative language teaching (CLT) cannot be seen as entirely applicable to Chinese learning cultures: The majority of principals and methods were developed for and continue to reflect "Western" educational and social cultural values (Richards and Rogers, 2014, p. 104). Although communicative approaches have been used in Chinese education from the early 1980s, CLT has not had the same level of influence as in other countries and other teaching methods are still widely used (McIntosh, 2016). One of the general misunderstandings among English teachers in China is that they think the more we teach, the more students can learn. However, what matters is not how much knowledge teachers share; it is how much information students can absorb through the 
way the subject is taught. EFL teachers in China can always find silent students in the classroom. Therefore, to help students achieve their development socially and academically, EFL teachers should focus on designing flexible teaching plans, making activities A, B C and D to adjust to all the students' needs, balance the time between teacher's instructing and students' performance, engaging students in communicative conversation (Prozesky, 2000), and cultivating communicative students. Rao (2006) concludes that CLT is not "completely suitable for all Chinese students" (p. 505) and recommends a reconciliation of the Grammar-Translation Method with "strategies that lead to a greater emphasis on communication" (p. 505). More recently, Zhang et al. (2013) found that CLT is "not culturally appropriate for the Chinese context" (p. 3); instead, they argued that the Context Approach was more suitable as it could help Chinese teachers introduce innovations based on their particular teaching situation.

There are doubts about the compatibility of CLT with education Chinese educational cultural (McIntosh, 2016). One problem is that Chinese students often do not perceive CLT as being serious study: they may enjoy communicative activities but do not accept that these will help towards the goal of acquiring the linguistic competency (specifically lexical and grammatical) required to pass an exam. Zhang et al. (2013) confirm that Chinese learners "tend to regard communicative activities as games for entertainment rather than a learning tool" (p. 3). Most official language examinations in China focus heavily on grammar competence; therefore, students expect to concentrate on learning new words and vocabulary in class, and generally "pay meticulous attention to language details rather than communicative competence” (Rao, 2002, p. 95). Such resistance may be seen as a preference toward the more traditional academic approaches 
deeply ingrained into the Chinese education system. Switching to a more communicative approach could be perceived as a lowering of academic prestige and esteem (Cook, 2008, p. 256).

Communicating in a second language is the way to stimulate learners' language acquisition, which will allow learners to use the language. Firstly, this requires teachers to provide comprehensible and complete information for students to practice and be productive (source). Secondly, teachers should create a friendly and comfortable classroom environment where students feel free to express themselves (form). Thirdly, the teacher should be aware of their role in planning and guiding, students are actually the ones who dominate the activity. Last but not least teacher should not correct students' grammar mistakes during the activity (feedback).

\section{Sociocultural Theory}

Personal development changes in personality take place as one grows. Social development changes over time in the ways we relate to others (Woolfolk, 1980). Sociocultural theory Emphasizes role in development of cooperative dialogues between children and more knowledgeable members of society (Vygotsky, 1987). Children learn the culture of their community (ways of thinking and behaving) through interactions (Giorgdze \& Dgebuadze, 2017).

\section{Interaction}

Theoretically, interaction is one of the ways to stimulate children's social development. Early in the period of the children's social development, maturation 
changes are brought about through learning, as individuals interact with their environment (Woolfolk, 1980). Interaction in activity influence changes in children's thinking, as well (Piaget, 1970a). A social process (or co-constructed process) is forming when children interact and negotiate to create an understanding and problem-solving skills (Nuttall, 2003). The zone of proximal development is a dynamic and changing space as student and teacher interact and understandings are exchanged. All students need to interact with teachers and peers in order to test their thinking, to be challenged, to receive feedback, and to watch how others work out problems (Woolfolk, 1980). Therefore, interactive activities are supposed to improve students' social skills and associate emotional development (Britt, Wilkins, Davis, \& Bowlin, 2017).

Vygotsky (1987) metaphorically describes social planes as precursors for the development of psychological planes. He pointed out that all functions, before being individually internalized, would be available in the social level. Accordingly, language acquisition process will start from interpsychological to intrapsychological, which means that language must be first interactional, and then internalized. The previous view is then confirmed by Nunn (2001), who stresses that social interaction is prerequisite to human cognitive development, a process from the interpersonal to intrapersonal level. Practically, when speakers frequently engage in the interaction with others, they must produce the understandable language, and try to understand what their interlocutors would like to convey (Nguyen, 2018). 


\section{Motivation}

Teachers are concerned about developing a particular kind of motivation in their students - the motivation to learn, defined as valuing academic activities and trying persistently to get benefit from them (Brophy, 1998, 2008). We may acquire a new skill or behavior through observation, but we may not perform that behavior until we have some motivation or incentive to do so (Woolfolk, 1980). Activities that are valued, not only for their utility in getting us to the next level but also simply for the enjoyment they bring, can lead us to deeper and more systematic engagement (Eccles, Fredricks, \& Baay, 2015). Therefore, students' knowing about what is needed to accomplish their individual learning goals is important, but it may not be sufficient. Motivation likely influences the degree to which students regulate their own learning (Woolfolk, 1980). Thus, it is always necessary to motivate students and most importantly to know their motivation.

\section{Experiential learning}

Gentry (1990) writes that "Experiential learning is participative, interactive, and applied.” (p. 20) Various terms have been used to label the process of learning from experience. Dewey (Dewey \& Dewey, 1915) discussed learning by doing, while Wolfe and Byrne (1975) used the term experienced-based learning. The term trial and error learning is used to explain inductive learning processes (Gentry, 1990). The AACSB Task Force ${ }^{4}$ (1986) used the term applied experiential learning, combining the learning from the real-world with the necessary condition of the application of concepts, ideas and

\footnotetext{
4 The Association to Advance Collegiate Schools of Business, also known as AACSB International, is an American professional organization. It was founded in 1916 to provide accreditation to business schools.
} 
theories to the interactive setting. Boggs, Mickel, \& Holtom (2007) related experiential learning with interactive learning, And Gentry (1990) include interactive is one of the criteria of experiential learning.

Interactive: As specified by the Task Force, the interaction involves more than just the instructor/student dyad. Student/student, student/client, or student/environment interaction is also required. Example interactions include group decision-making in a simulation game, presentations to clients in small business case projects, and conducting survey research of local households for a marketing research course project. (Gentry, 1990, p. 13)

The essence of experiential learning is learning by doing, which specifically refers to the act of learner's taking in knowledge through their active and experiential participation in activities (Nguyen, 2018). And for young children, their experience of fun learning comes from playing (Waite, 2017). England's Department for Education (DfE), within its Early Years Foundation Stage (EYFS) framework, ${ }^{5}$ identifies three important dimensions for children to apply experiential learning:

- $\quad$ Playing and exploring - children investigate and experience things, and 'have a go';

- Active learning - children concentrate and keep trying if they encounter difficulties and enjoy achievements; and

- Creating and thinking critically - children have and develop their own ideas, make links between ideas, and develop strategies for doing things. (DfE, 2014, p. 9)

Modern teaching expects from an individual continuous learning, creativity and exploration (Knežević \& Kovačević, 2010). Students are expected not only to manage their own potentials, knowledge, skills and habits, but also to discover and examine their own talents and areas of interest. All this requires an environment that is rich in stimuli

\footnotetext{
5 The Early Years Foundation Stage (EYFS) sets standards for learning, development and care for children from birth to five years old.
} 
and challenges for a child (Roeders, 2003, p. 83). It also requires an interactive circumstance where children can learn from their experiences.

For elementary school students, experiential learning is not only learning by playing (Waite, 2017) but also learning by guessing (Lefstein \& Snell, 2011) and learning by creating (DfE, 2014). Interactive activities are mostly levied in the form of playing games in English class in Chinese elementary school. For example, when we distribute the questionnaire, as we explain interactive activities to the participants in elementary schools in China, the most helpful example is an interactive game.

\section{Comprehensible Input, and the Comprehensible Output Hypothesis}

When learning a second language, learners are expected to be involved in the process of intercommunication, exchanging information, and negotiating meaning for mutual understanding, concurrently leading to learners' acquiring language forms (Lightbown \& Spada, 2013). Thus, interaction plays the central role in helping learners acquire the language. In order to be successful in interaction, it is necessary for interlocutors to modify both input and output (Nguyen, 2018).

Gass (1997), Hatch (1978), Long (1983, 1996), Mackey (1999), and Pica (1994), as well as many other researchers have stressed how necessary conversational interaction is to the success of second language acquisition. Where there exists mutual interaction, language development takes place. Ellis and He (1999) affirm that dialogical interaction brings learners much more opportunities to expand their repertoire of lexical knowledge than monologue-constructed learning format. The linguistic phenomenon is brought out by the need of making interaction and meaning negotiation. Interlocutors are supposed to 
modify their speech and make the best use of communication strategies to maintain the conversation.

The comprehensible input hypothesis that comes from a composite of five hypotheses (the acquisition/learning hypothesis, the monitor hypothesis, the natural order hypothesis, the input hypothesis, and the affective filter hypothesis) is an attempt at describing the dynamic breadth of second language acquisition processes (Krashen, 1985). The comprehensible input hypothesis, or $i+1$, indicates that new language delivered to learners should be mostly intelligible to them without discouraging them from understanding it. During their conversations, they need to modify their speech to make it intelligible and keep them involved in the interpersonal communication. Obviously, according to this theory, comprehensible input $(i+1)$ is important for the process of language acquisition (Nguyen, 2018). In order to have comprehensible input, it requires modified interaction, which is regarded as the key of language development to interlocutors. Interaction modification is not always related to linguistic simplification. It can be composed of an array of such strategies as body language, a slower rate of speech, and additional explanation.

As to the crucial elements for the success of second language learning, Swain (1985) first introduced the Comprehensible Outcome Hypothesis. Indicated in the hypothesis is that in order to communicate successfully, interlocutors need to produce comprehensible language, making them aware of what they need to improve and how they can improve in their second language capacity. Through negotiation meaning, interlocutors are able to create comprehensible input and output, an integral part to insure successful interaction. Particularly, in both speaking and listening, such a communicative 
strategy is considered to be crucial for the process of comprehension and language acquisition (Pica, Holliday, Lewis, \& Morgenthaler, 1989).

Huynh (2017) applied the concepts of comprehensible input and output in modifying instruction. He saw comprehensible output to mean anything the student is doing to demonstrate understanding. This can mean engaging in learning experiences or completing assessments. Huynh (2017) borrowed the term comprehensible output because content teachers usually need help in getting English learners (ELs) to understand instruction (comprehensible input) and determining if the English learns understand the instruction (comprehensible output). The output produced by ELs indicates the degree to which they comprehend the instructions and content (p. 1). With the formative information, teachers can modify instruction. Comprehensible output is the belief that ELs can communicate at the level of their language proficiency (Huynh, 2017). Forcing an EL to communicate in ways that are beyond their current language capabilities often frustrates them and creates an emotional distance between them and school. After ELs understand the instructions, teachers should offer differentiated tasks that allow them to communicate their understanding in alternative forms and in ways that honor their current language development (Huynh, 2017).

\section{Synopsis of Literature Review}

As early as 1952, education in China was fully integrated into the national unified plan (OECD, 2016). The examination-oriented teaching mode, limited students'

development (Lu, Tang, \& Luo, 2007). English was officially introduced as a compulsory 
subject in Chinese elementary school (MEC, 2001) in 2001; however, under the examoriented education background (Zha, 2015), students were bored while English learning. Optimistically, with the revised English Curriculum Standards for Compulsory Education in 2011, Chinese English teachers tend to focus more on the students' learning process and start to switch from teacher centered teaching mode to student-centered, innovative, flexible and cooperative teaching mode (Zhou, 2018). The New Basic Education Project started from 1994 but had developed in the early 21st century (Ye, 2006, Li, Wang, \& Chen, 2013; Li \& Li, 2015; Li, 2015). It emphasized students' innovative practice, teacher-student interaction, classroom activities, the revision and rebuilding of teaching behaviors, and other issues related to children's holistic development. Thus, interactive activities merged in Chinese English class and carried forward to promote students EFL skills and social development.

The conceptual framework of my thesis includes Communicative Language Teaching, Sociocultural Theory, Experiential Learning, Comprehensible Input, and the Comprehensible Output Hypothesis. They overlap with each other, and the intersections is interaction. Communicative or interactive teaching and learning indicate ways to give instruction, and offer feedback and revision, and assess student accomplishments. The study of students' motivation and social and emotional development are important foci of sociocultural theory and experiential learning. In order to be successful in interaction, students need to modify both input and output, which are key in language development. The comprehensible input and output hypothesis explains second language acquisition processes (Krashen,1985) and emphasizes the importance of communication, through which interlocutors are able to create comprehensible input and output, both integral 
components of language learning to insure successful interaction (Pica, Holliday, Lewis, \& Morgenthaler, 1989). Thus, reflective examination of comprehensible input and output can support teachers in their metacognitive approaches toward giving instruction (Huynh, 2017), while allowing interlocutors to reflect on their language development. 


\section{CHAPTER III}

\section{METHODOLOGY}

In an effort to understand young students' impressions, a questionnaire was designed to focus on the following: Chinese students' understanding of and their achievement with respect to EFL interactive activity. The model of the questionnaire is based on Gu, Yin, and Li's (2015) study regarding students' responses to homework in China. In my thesis, much like Gu et al., reference to students' understanding includes their value, motivation, participation, and attitudes toward teachers' instruction, revision and teaching materials, as well as their expectations of teaching style and tools. Similarly, a motivation for implementing a version of their questionnaire was to apply their conceptualization of achievement, which was shown to consist of assessment with respect to academic and social development (Gu, Yin, \& Li, 2015).

This thesis implemented quantitative data analyses. The quantitative data in the form of descriptive statistics served to describe students' understanding and achievement of the EFL interactive activity. This section attempts to lend insight into how the research data were collected. Specifically, the information of the participants, the research setting, the instruments, and the procedure are included. 
As a result of a review of literature, the following research questions emerged:

1. What does interactive teaching mean to elementary aged Chinese students when studying English?

a. What may be some different attitudes from different age/gender groups with respect to interactive activity?

b. What might be some important elements in interactive activity from elementary school students' perspective?

c. What types of instruction seem to be more acceptable for elementary school students when implementing interactive activities?

d. How might revision and feedback from teachers help students' English learning?

2. What is the effect of interactive teaching in EFL classes on the development of elementary aged Chinese students, both academically and socially?

a. How might interactive activity help students improve scores in traditional English tests?

b. How might interactive activity help raise students' learning ability and confidence, and assist in their motivation?

As a foundation to answer these questions, as mentioned previously, I looked to the work of Gu, Yin, and $\mathrm{Li}$ (2015), who studied Chinese students' response to homework. In their study, they discussed Chinese students' attitude towards happy homework (homework that students name as easy and fun, that has students achieving tasks at one stroke, and that has children and parents purportedly improving themselves together). Gu et al. were particularly interested in any effect happy homework might have 
on students' academic, emotional and social development. To perform their study, they developed an 11-category questionnaire with 47 multiple choice questions designed for young children and their parents in elementary school in China. The researchers found that $100 \%$ of the students and parents were "very satisfied" with happy homework, while $100 \%$ of the students and $98 \%$ of the parents agreed that happy homework brought happiness. The result of this research was lauded to the extent that it was included in a national teachers event called the 10 Highlight Events of 2014 (Gu, Yin, and Li, 2015), where happy homework was spotlighted as one of ten key concepts for teachers to know that year.

A key element of Gu et al.'s concept of a happy homework-related questionnaire entailed several question categories - value, participation, instruction, revision, general assessment, academic development, emotional and social development. For the purpose of answering the research questions of my thesis, and based on the structures established by $\mathrm{Gu}$, Yin and Li, I created a survey of Likert scale and open-ended questions in an effort to help catch the close-up reality of participants' experiences of interactive activities in their English classroom.

Table 1 offers a snapshot of how the literature corresponds to the methodological structure and displays the following elements: the research question, any subsidiary related sub-questions, connections to the literature described in Chapter II, corresponding categories named by $\mathrm{Gu}$ et al., and the actual survey questions posed to the children. 
Table 1: Categories of questionnaire items

\begin{tabular}{|c|c|c|c|c|}
\hline $\begin{array}{l}\text { General } \\
\text { research } \\
\text { question }\end{array}$ & $\begin{array}{l}\text { Sub-research } \\
\text { question }\end{array}$ & Influence from literature & Category & Specific question in survey \\
\hline \multirow{21}{*}{$\begin{array}{l}\text { RQ1: } \\
\text { What does } \\
\text { interactive } \\
\text { teaching mean } \\
\text { to elementary } \\
\text { aged Chinese } \\
\text { students when } \\
\text { studying } \\
\text { English? }\end{array}$} & \multirow{12}{*}{$\begin{array}{l}\text { a) Different } \\
\text { attitudes from } \\
\text { different } \\
\text { age/gender } \\
\text { groups with } \\
\text { respect to } \\
\text { interactive } \\
\text { activity. }\end{array}$} & \multirow{3}{*}{$\begin{array}{l}\text { Algonquin College, n.d. } \\
\text { Eccles, Fredricks, \& Baay, 2015; } \\
\text { Brophy, 1998, 2008; }\end{array}$} & \multirow[t]{3}{*}{ Motivation } & $\begin{array}{l}\text { Q1: I want to do the interactive activities because I } \\
\text { can learn happily }\end{array}$ \\
\hline & & & & $\begin{array}{l}\text { Q2: I want to do the interactive activities because it } \\
\text { kills the class time }\end{array}$ \\
\hline & & & & $\begin{array}{l}\text { Q3: I do the activity because the teacher asks us to } \\
\text { do }\end{array}$ \\
\hline & & \multirow{5}{*}{$\begin{array}{l}\text { Giorgdze \& Dgebuadze, 2017; } \\
\text { Senthamarai, 2018; }\end{array}$} & \multirow[t]{5}{*}{ Value } & Q4: I like the interactive activities \\
\hline & & & & $\begin{array}{l}\text { Q5: I think interactive activities is important in class } \\
\text { learning }\end{array}$ \\
\hline & & & & Q6: I think interactive activities helps my learning \\
\hline & & & & Q7: I wish I can do well in interactive activities \\
\hline & & & & $\begin{array}{l}\text { Q8: I think doing interactive activity is a waste of } \\
\text { time }\end{array}$ \\
\hline & & \multirow[t]{4}{*}{ Gentry, 1990} & \multirow[t]{4}{*}{ Participation } & Q9: I am willing to do the interactive activity \\
\hline & & & & Q10: I fully participate in interactive activities \\
\hline & & & & $\begin{array}{l}\text { Q11: I want to do the interactive activities the whole } \\
\text { class }\end{array}$ \\
\hline & & & & $\begin{array}{l}\text { Q12: I want to do the interactive activities the partly } \\
\text { in class }\end{array}$ \\
\hline & \multirow{5}{*}{$\begin{array}{l}\text { b) What types of } \\
\text { instruction seem } \\
\text { to be more } \\
\text { acceptable for } \\
\text { elementary } \\
\text { school students } \\
\text { when } \\
\text { implementing } \\
\text { interactive } \\
\text { activities. }\end{array}$} & \multirow{5}{*}{$\begin{array}{l}\text { Concordia University Portland; } \\
\text { Communicative language } \\
\text { teaching (CLT) } \\
\text { Sowell, } 2017 \\
\text { Salaberri } 1995 \\
\text { Huynh, } 2017\end{array}$} & \multirow[t]{5}{*}{ Instruction } & $\begin{array}{l}\text { Q13: I prefer the teacher instruct in only Chinese } \\
\text { language }\end{array}$ \\
\hline & & & & $\begin{array}{l}\text { Q14: I prefer the teacher instruct in only Chinese } \\
\text { language }\end{array}$ \\
\hline & & & & $\begin{array}{l}\text { Q15: I hope the teacher can use both English and } \\
\text { Chinese in instruction }\end{array}$ \\
\hline & & & & $\begin{array}{l}\text { Q16: I can understand the teacher if she/he uses the } \\
\text { English instruction with body language }\end{array}$ \\
\hline & & & & $\begin{array}{l}\text { Q17: I can understand the teacher if she/he uses the } \\
\text { English instruction with body language and } \\
\text { examples }\end{array}$ \\
\hline & \multirow{2}{*}{$\begin{array}{l}\text { c) How well do } \\
\text { teachers handle } \\
\text { problems and } \\
\text { give feedback to } \\
\text { help students' } \\
\text { English learning? }\end{array}$} & \multirow{2}{*}{$\begin{array}{l}\text { ARMA International Center for } \\
\text { Education; } \\
\text { Eight Ways Teachers Can Talk } \\
\text { Less and Get Kids Talking } \\
\text { More ; } \\
\text { Communicative language } \\
\text { teaching (CLT) } \\
\text { Brown 2000; } \\
\text { Nguyen 2018 }\end{array}$} & \multirow[t]{2}{*}{ Revision } & $\begin{array}{l}\text { Q18: Teachers often handle the problem occurred in } \\
\text { activities }\end{array}$ \\
\hline & & & & $\begin{array}{l}\text { Q19: Teacher often give discussion and feedback } \\
\text { after the activities }\end{array}$ \\
\hline & \multirow[b]{2}{*}{$\begin{array}{l}\text { What might be } \\
\text { important } \\
\text { elements in } \\
\text { interactive } \\
\text { activity from } \\
\text { elementary } \\
\text { school students' } \\
\text { perspective? }\end{array}$} & \multirow{2}{*}{$\begin{array}{l}\text { Communicative language } \\
\text { teaching (CLT) }\end{array}$} & \multirow[t]{2}{*}{ Tools } & Q20: I like the activities with music \\
\hline & & & & $\begin{array}{l}\text { Q22: I like the interactive activities with } \\
\text { competitions and awards }\end{array}$ \\
\hline \multirow{10}{*}{$\begin{array}{l}\text { What is the } \\
\text { effect of } \\
\text { interactive } \\
\text { teaching in } \\
\text { EFL classes on } \\
\text { the } \\
\text { development } \\
\text { of elementary } \\
\text { aged Chinese } \\
\text { students, both } \\
\text { academically } \\
\text { and socially? }\end{array}$} & \multirow{7}{*}{$\begin{array}{l}\text { To what extent } \\
\text { do students and } \\
\text { teachers satisfy } \\
\text { with the } \\
\text { interactive } \\
\text { activity? }\end{array}$} & \multirow[t]{7}{*}{ Yee (2019) } & \multirow[t]{7}{*}{$\begin{array}{l}\text { General } \\
\text { Assessment }\end{array}$} & $\begin{array}{l}\text { Q23: I am quite satisfied with the interactive } \\
\text { activities }\end{array}$ \\
\hline & & & & $\begin{array}{l}\text { Q24: Teachers are quite satisfied with our } \\
\text { performance in interactive activities }\end{array}$ \\
\hline & & & & $\begin{array}{l}\text { Q25: I didn't learn anything from the interactive } \\
\text { activities }\end{array}$ \\
\hline & & & & $\begin{array}{l}\text { Q26: My classmates often complain about the } \\
\text { interactive activities }\end{array}$ \\
\hline & & & & $\begin{array}{l}\text { Q27: I can remember the language point after the } \\
\text { interactive activities }\end{array}$ \\
\hline & & & & $\begin{array}{l}\text { Q28: I can learn what I suppose to learn through the } \\
\text { interactive activities }\end{array}$ \\
\hline & & & & Q29: I learned nothing from the interactive activities \\
\hline & \multirow{3}{*}{$\begin{array}{l}\text { How might } \\
\text { interactive } \\
\text { activity help } \\
\text { students improve } \\
\text { scores in } \\
\text { traditional } \\
\text { English tests? }\end{array}$} & \multirow[t]{3}{*}{ MacKenzie \& Ballard, 2015} & \multirow{3}{*}{$\begin{array}{l}\text { Academic } \\
\text { Developmen } \\
\mathrm{t}\end{array}$} & $\begin{array}{l}\text { Q30: I do well in the interactive activities and I get a } \\
\text { good test score }\end{array}$ \\
\hline & & & & $\begin{array}{l}\text { Q31: I do well in the interact activities and it } \\
\text { improve my test score. }\end{array}$ \\
\hline & & & & $\begin{array}{l}\text { Q32: I do well in the interactive activities even } \\
\text { though my test score doesn't improve, my listening } \\
\text { and speaking skills are improved }\end{array}$ \\
\hline
\end{tabular}




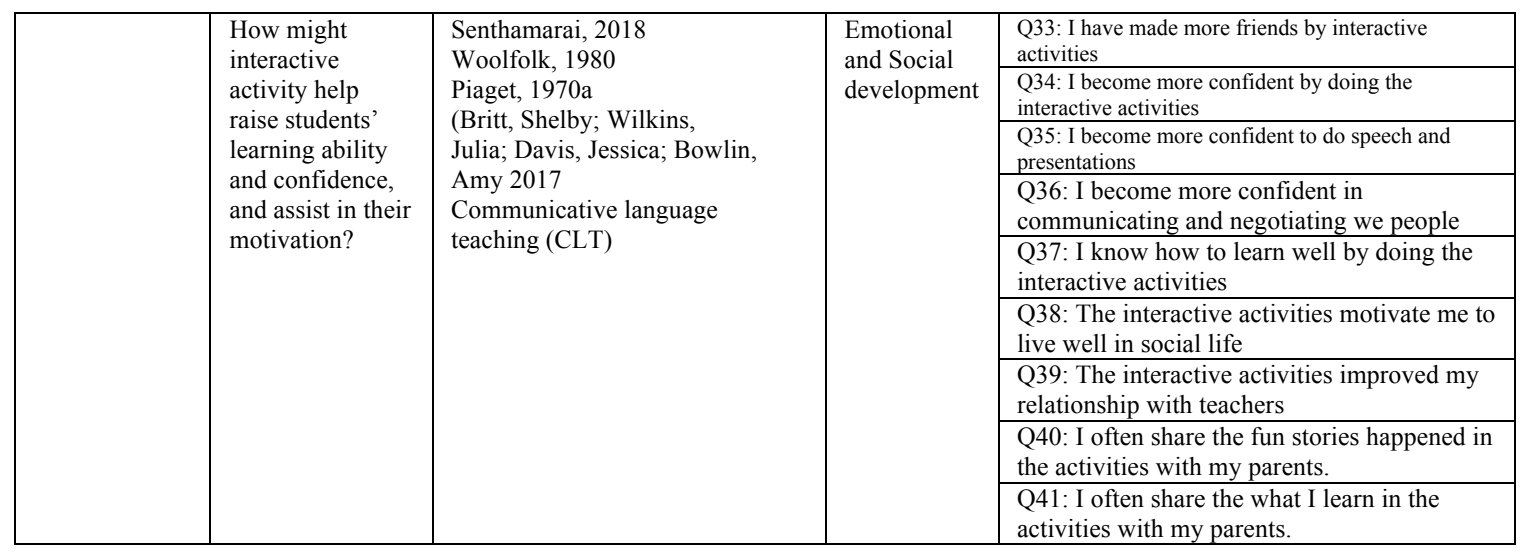

\section{Research procedure}

\section{Research setting}

I conducted the research with the cooperation of three educational institutes with students from multiple schools in the city of Xuzhou, Jiangsu, China. In each of these institutions, students attend after school programs to improve their English skills as well as their academic subjects.

\section{Recruiting of subjects}

Students participating in after school programs were given a chance to participate. They were alerted to the process, along with their parents, before participating. Parents, who were picking up their children from class, received written consent forms. They were asked to take them home to ponder the idea of their children's participation and return a signed form if they consented to their child's partaking. Parents and students were both alerted to FIU's practice of not requiring participation, allowing students to drop out should they decide to without penalty. Both parents and students received notice of the project and were given at least an overnight period (sometimes longer) to 
determine whether student participation would be appropriate for them. A number of parents, however, were willing to sign the forms straight away.

Students were neither sought out or excluded due to particular defined circumstances - for example, special needs, socioeconomic status, or ethnicity (please see the limitations section in Chapter 5 for further discussion). All subjects were between the ages of 9 and 12. Students were not compensated in any way to be participants in the study.

Generally speaking, the subjects were recruited with following steps:

1. During a holiday trip to southwestern China, I visited the educational institutes in Xuzhou, Jiangsu, China. I explained the purpose of the study and permission of each institute's director to conduct the research. I then requested a letter from the contributing institute regarding their consent for the purpose of the Institutional Review Board. Each support letter may be seen in Appendix A.

2. As soon as the educational institute leadership signed the consent letter, the directors of the institutes assisted in distributing consent letter to parents and their children. Parent and student consent letter templates may be found in Appendix B.

3. If students and their parents both agreed to participate with the questionnaire-in other words, they signed the consent letter - the institutes scheduled a time for the teaching assistant, my mother, and me, participating online via the WeChat app, to distribute the questionnaire and give instructions about it. The corresponding flyer may be found in Appendix B. 


\section{Consent}

In consultation with my institution's Institutional Review Board officials, I negotiated a plan for achieving consent from both families and their children. I requested consent forms from both the potential child participants and their families. Consent forms were delivered to one parent and their child at the site. Both parent and child were to sign the form. Forms were collected and kept in a trackable envelope. This was then sent to me via express mail. Upon receipt of this envelope, as indicated through a required signature, the forms were kept in a locked filing cabinet.

\section{Participants}

The majority of Chinese students begin to learn English at age nine. Little information is known about students' affective responses to certain activities in Chinese settings. Thus, I wanted to ask children, especially those just starting out with their English learning, about their impressions. Thus, only students between ages 9 and 12 (inclusive) were included in the subject pool.

Since the after-school programs do not include grading, neither families nor students were under threat of consequences had they opted not to participate.

The original goal of the thesis was to receive at least 100 filled-in questionnaires. Therefore, 146 questionnaires were distributed. However, only 67 of the available questionnaires were used. All 67 participating elementary school students were from grades three to six. While I did not achieve a goal of 100 forms, the participation rate was still greater than that of Gu, Yin, and Li's (2015) study, which included only 
48 participants. My study represents a subset of students attending extracurricular institutions.

\section{Procedure}

In accordance with procedures agreed upon in concert with my institution's Institutional Review Board, I was in Miami during data collection but was in synchronous communication with each research site via WeChat Video (similar to Skype). In fact, during all sessions of consent form collection and data collection, I synchronously monitored the activity via WeChat video and was immediately available through WeChat, should any question arise unexpectedly.

Instructions to my mother, the director of the school, and to the participants were the following:

1. The school assistant confirmed permission from parents and guardians.

2. The school assistant distributed assent forms to participating students for signatures; forms were collected once forms were completed.

3. Students who signed their consent letter and who possessed a consent letter signed by a parent were chosen to watch pictures of interactive activities in English classrooms. 

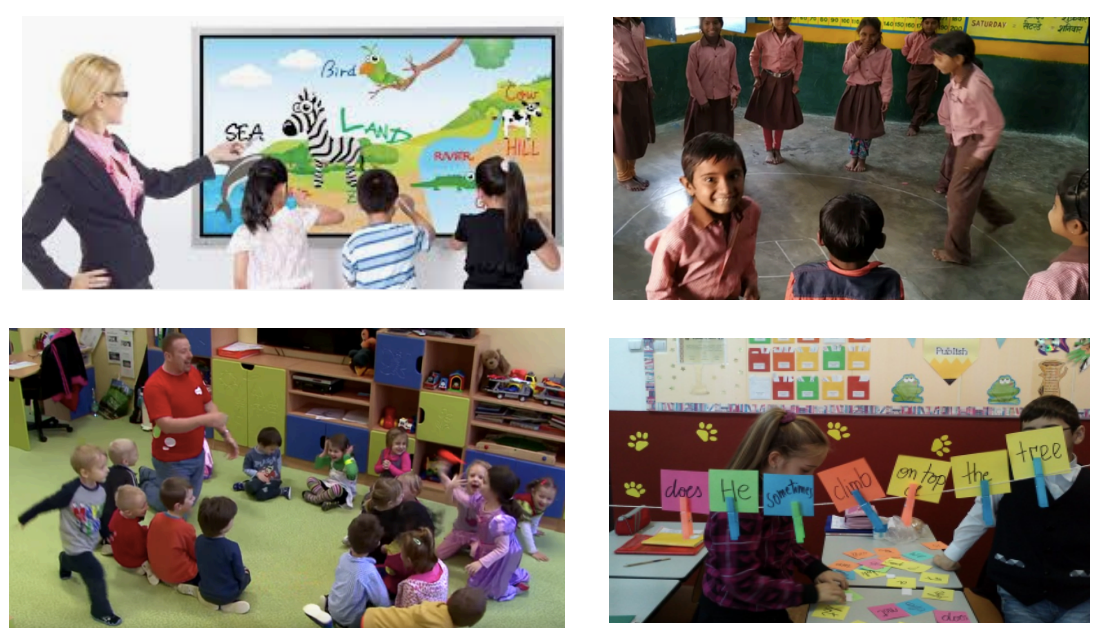

Figure 2. Pictures showing interactive activities

4. The school assistant asked students whether they had ever experienced situations depicted in the pictures, or if they had ever played games in English classes.

5. The school assistant gathered students with "yes" answers in step 4 together in a new room and distributed a new flyer (see Appendix C) to the students. Upon passing out the flyers, the assistant read the following statement:

Whether you like English or not, whether you had fun learning experience in English class or not, if you ever participated in interactive learning activity in your English class, we would love to know how you were influenced by those activities.

Would you like to take an opportunity to create your critical thinking, make your voice heard, while contributing to improving the quality of English teaching in Chinese elementary school? If your answer is yes, please take and complete the survey authentically and seriously.

Students were asked to answer questions in accordance with their genuine experience.

6. Students handed the completed survey to the school assistant. 
7. I, the student researcher, was available for immediate communication should questions arise.

The entire questionnaire was administered at the school sites. Questionnaires were collected immediately upon completion. Students were not interviewed; instead, they provided self-generated answers by writing on the form itself. I was available synchronously via WeChat Video in case any questions arose.

The survey was conducted in Mandarin. Professional terms were avoided while easy, comprehensible, children-friendly language and patterns (stars rank, smiling faces) will be adopted into the questionnaire. Data to be collected were paper-based. Initial consent forms were also paper-based.

\section{Distribution of the survey}

Questionnaires were paper-based. No identifiable information was collected from questionnaires. Questionnaires were distributed to student subjects by my mother. She similarly collected the materials, of which the questionnaires maintained participant anonymity.

The survey was designed such that student participants would need no more than 10 to 15 minutes to complete it. Both my mother and the school directors confirmed that questionnaires were indeed completed within this time period.

\section{Transfer of information}

Upon collection of the consent forms and questionnaires, forms were taken to the home of my mother. Those were placed in a sealed envelope which was sent via express 
mail, complete with tracking numbers and a request for my signature upon receipt. Upon receipt of consent forms and data, materials were stored in a locked filing cabinet. Data were neither transferred nor stored electronically.

\section{Data collection}

By finishing the collection of consent letters and scheduling with the subjects, questionnaires were distributed to the participants. The instrument borrowed the framework from $\mathrm{Gu}$, Yin, and $\mathrm{Li}$ (2015) to assess students' attitudes towards interactive activities in English class and the influence interactive activities may contribute to students' academic, emotional and social development. The questionnaire has nine categories and 41 questions (statements). Students were asked to make a mark corresponding to a number of stars representing the extent of student's agreement. Five stars meant very much agree, four stars meant agree, three stars meant unsure, two stars meant disagree, and one star meant very much disagree. The participants answered the questionnaire by checking the number of stars per question. For example, if the participants strongly agreed with the statement, they should check for five stars in the related curriculum (see the instrument in Table 2). The research instrument began by asking students to answer the following questions:

- I am ___ years old I'm in grade

- I am a (Boy/girl) 
Table 2. The questionnaire.

\begin{tabular}{|c|c|c|c|c|c|c|}
\hline Category & Question & 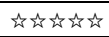 & 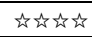 & 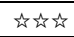 & 论的 & is \\
\hline \multirow[t]{3}{*}{ Motivation } & I want to do the interactive activities because I can learn happily & & & & & \\
\hline & I want to do the interactive activities because it kills the class time & & & & & \\
\hline & I do the activity because the teacher asks us to & & & & & \\
\hline \multirow[t]{5}{*}{ Value } & I like the interactive activities & & & & & \\
\hline & I think interactive activities is important in class learning & & & & & \\
\hline & I think interactive activities helps my learning & & & & & \\
\hline & I wish I can do well in interactive activities & & & & & \\
\hline & I think doing interactive activity is a waste of time. & & & & & \\
\hline \multirow[t]{4}{*}{ Participation } & I am willing to do the interactive activity & & & & & \\
\hline & I fully participate in interactive activities & & & & & \\
\hline & I want to do the interactive activities the whole class & & & & & \\
\hline & I want to do the interactive activities the partly in class & & & & & \\
\hline \multirow[t]{5}{*}{ Instruction } & I prefer the teacher instruct in only Chinese language & & & & & \\
\hline & I prefer the teacher instruct only in English language & & & & & \\
\hline & I hope the teacher can use both English and Chinese in instruction & & & & & \\
\hline & $\begin{array}{l}\text { I can understand the teacher if she/he uses the English instruction } \\
\text { with body language }\end{array}$ & & & & & \\
\hline & $\begin{array}{l}\text { I can understand the teacher if she/he uses the English instruction } \\
\text { with body language and examples }\end{array}$ & & & & & \\
\hline \multirow[t]{2}{*}{ Revision } & Teachers often handle the problem occurred in activities & & & & & \\
\hline & Teacher often give discussion and feedback after the activities & & & & & \\
\hline \multirow[t]{3}{*}{ Forms } & I like the activities with music & & & & & \\
\hline & I like the activities with pictures and videos & & & & & \\
\hline & I like the interactive activities with competitions and awards & & & & & \\
\hline \multirow{7}{*}{$\begin{array}{l}\text { General } \\
\text { Assessment }\end{array}$} & I am quite satisfied with the interactive activities & & & & & \\
\hline & $\begin{array}{l}\text { Teachers are quite satisfied with our performance in interactive } \\
\text { activities }\end{array}$ & & & & & \\
\hline & I didn't learn anything from the interactive activities & & & & & \\
\hline & My classmates often complain about the interactive activities & & & & & \\
\hline & I can remember the language point after the interactive activities & & & & & \\
\hline & $\begin{array}{l}\text { I can learn what I suppose to learn through the interactive } \\
\text { activities }\end{array}$ & & & & & \\
\hline & I learned nothing from the interactive activities & & & & & \\
\hline \multirow{3}{*}{$\begin{array}{l}\text { Academic } \\
\text { development }\end{array}$} & I do well in the interactive activities, and I get good test scores & & & & & \\
\hline & I do well in the interact activities, and it improve my test scores. & & & & & \\
\hline & $\begin{array}{l}\text { I do well in the interactive activities even though my test score } \\
\text { doesn't improve, my listening and speaking skills are improved }\end{array}$ & & & & & \\
\hline \multirow{9}{*}{$\begin{array}{l}\text { Emotional } \\
\text { and social } \\
\text { development }\end{array}$} & I have made more friends by interactive activities & & & & & \\
\hline & I become more confident by doing the interactive activities & & & & & \\
\hline & I become more confident to do speech and presentations & & & & & \\
\hline & $\begin{array}{l}\text { I become more confident in communicating and negotiating we } \\
\text { people }\end{array}$ & & & & & \\
\hline & I know how to learn well by doing the interactive activities & & & & & \\
\hline & The interactive activities motivate me to live well in social life & & & & & \\
\hline & The interactive activities improved my relationship with teachers & & & & & \\
\hline & $\begin{array}{l}\text { I often share the fun stories happened in the activities with my } \\
\text { parents. }\end{array}$ & & & & & \\
\hline & I often share the what I learn in the activities with my parents. & & & & & \\
\hline
\end{tabular}

\section{Remark:}

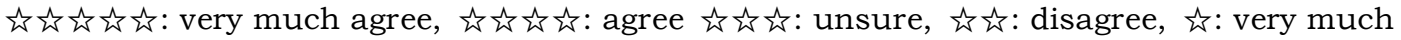
disagree 
Thus, I only asked about age, grade, and gender. Table 2 displays the questionnaire (with English translation) offered to the students. The bulk of the measurement instrument follows survey designs established by Jazbec, Cagran \& Ostir (2016) and Gu, Yin, and Li’s (2015).

\section{Data Analysis}

From the three questionnaire distribution opportunities, 146 papers were given to students and 143 were collected. In the questionnaire, question 25 "I didn't learn anything from the interactive activity" and question 29 "I learned nothing from the interactive activity" were designed to assess if students were taking the survey seriously. If students didn't give the same answer to those two questions, their data were not used. In this case, from the 143 papers, only 67 of them achieved this standard. Among the 67 participants, 37 of them were girls and 30 of them were boys. The gender and age range of the participants was the following:

Table 3. Sample pool.

\begin{tabular}{|c|c|c|c|}
\hline Age & Number of Girls & Number of Boys & subtotal \\
\hline Nine & 7 & 5 & 12 \\
\hline Ten & 11 & 12 & 23 \\
\hline Eleven & 11 & 8 & 19 \\
\hline Twelve & 8 & 5 & 13 \\
\hline Subtotal & 37 & 30 & 67 \\
\hline
\end{tabular}




\section{Role of the researcher ${ }^{6}$}

I grew up in the city where the research was conducted. I am a native speaker of Mandarin, the language in which the study was conducted. To my knowledge, there were no local rules, laws, ordinances, or regulations that would have precluded this project.

\section{Ethical Considerations}

Collected data were anonymous. Privacy was assured since demographic data such as name, address, phone number, or other related data were not to be collected. Only the research team had access to the data. Names of students were not requested on data collection papers. In addition to the research team, only the mother of the student researcher had temporary access to the materials and sealed the data collection forms right away for international mail. Questionnaire information was conducted without connecting information and was collected immediately upon completion. Data were stored in locked filing cabinets and were transferred via express mail requiring tracking numbers and signatures for delivery.

I did not associate any known risk or harm with the completion of such surveys. To my knowledge, no survey question left me expecting undue negative influence on students' wellbeing. Furthermore, the questionnaires were conducted with anonymity as

\footnotetext{
${ }^{6}$ For this thesis, a native speaker refers to a student raised in an education context placed by Chinese public schools. Unlike US contexts, this term does not necessarily represent students designated as emergent bilinguals and presumes students who seeming require no linguistic accommodations in order to operate casually in a Mandarin-medium setting and have never perceptively needed any. However, there is no intent to ignore critiques of the term which pose native speaker as a lofted position upon a linguistic hierarchy (Skutnabb-Kangas, 2006).
} 
part of the information collection structure; thus, I expected no issue regarding confidentiality or privacy.

The risk level in relation to the procedures was akin to that in normal life. The activity entailed no more risk to the participants than providing information for the survey. There were no known risks associated with this activity with respect to physical psychological, social, legal, or economic experiences.

\section{Back translation}

In accordance with my institution's Institutional Review Board, under conditions of using a language other than English, I was required to attach both the English version and Mandarin version of consent forms and the questionnaire. Since the translation was not accomplished by a professional translation service, I completed a back-translated version of each of these documents. Each attachment needed to be clearly labeled to differentiate between the English version, the Translated version in Mandarin, and the back-translated version.

The back translator is a native speaker of Mandarin Chinese, who had passed appropriate examinations in order to participate in English at FIU.

The back translation documents are included in Appendix D. 


\section{CHAPTER IV}

\section{RESULTS}

This thesis was designed to study the meaning of interactive activity with respect to elementary aged Chinese students in English classes and the effect of interactive teaching in EFL classes in terms of the development of elementary aged Chinese students, academically, emotionally and socially. To examine the issue, the attitudes from different age/gender groups regarding interactive activity, the best teaching form and the instruction giving interactive activity will be discussed. Meanwhile, the data from the questionnaires are also able to show teachers' revision, teachers' and students' satisfaction of the interactive activities. In this chapter we can also find out to what extent do interactive activities help students' learning, and raise their confidence, how interactive activity help students improve English test scores and their learning ability.

\section{RESULTS}

Results of this study are presented with respect to the research questions and their corresponding subsidiary questions. 


\section{What does interactive teaching mean to elementary aged Chinese students when}

\section{studying English?}

\section{a. What are some attitudes from different age/gender groups regarding interactive activity?}

To answer this question, questions 1 through 12 of the main questionnaire (see

Table 2) apply to Chinese elementary school students' attitudes to interactive English activities. Results of the questionnaire regarding these attitudes are shown in Table 4.

Table 4. Attitudes of all participants.

\begin{tabular}{|c|c|c|c|c|c|c|c|c|c|c|c|c|c|c|}
\hline \multirow[b]{3}{*}{$\begin{array}{l}\text { Cate- } \\
\text { gory }\end{array}$} & \multirow[b]{3}{*}{ ? } & \multirow[b]{3}{*}{ questions } & \multicolumn{12}{|c|}{ All students $\mathrm{N}=67$} \\
\hline & & & \multicolumn{2}{|c|}{$\begin{array}{l}\text { very much } \\
\text { agree }\end{array}$} & \multicolumn{2}{|c|}{ agree } & \multicolumn{2}{|c|}{ unsure } & \multicolumn{2}{|c|}{ disagree } & \multicolumn{2}{|c|}{$\begin{array}{l}\text { very much } \\
\text { disagree }\end{array}$} & \multirow[b]{2}{*}{$\begin{array}{l}\text { me } \\
\text { an }\end{array}$} & \multirow[b]{2}{*}{ SD } \\
\hline & & & $\mathrm{N}$ & $\%$ & $\mathrm{~N}$ & $\%$ & $\mathrm{~N}$ & $\%$ & $\mathrm{~N}$ & $\%$ & $\mathrm{~N}$ & $\%$ & & \\
\hline \multirow[b]{3}{*}{$\begin{array}{l}\text { Moti- } \\
\text { vation }\end{array}$} & Q1 & $\begin{array}{l}\text { I want to do the } \\
\text { interactive activities } \\
\text { because I can learn } \\
\text { happily }\end{array}$ & 54 & $81 \%$ & 5 & $7 \%$ & 5 & $7 \%$ & & & 3 & $4 \%$ & $\begin{array}{r}4.6 \\
0\end{array}$ & 0.96 \\
\hline & Q2 & $\begin{array}{l}\text { I want to do the } \\
\text { interactive activities } \\
\text { because it kills the } \\
\text { class time }\end{array}$ & 6 & $9 \%$ & 6 & $9 \%$ & 6 & $9 \%$ & 4 & $6 \%$ & 45 & $67 \%$ & $\begin{array}{r}1.8 \\
7\end{array}$ & 1.38 \\
\hline & Q3 & $\begin{array}{l}\text { I do the activity } \\
\text { because the teacher } \\
\text { asks us to do }\end{array}$ & 15 & $22 \%$ & 10 & $15 \%$ & 7 & $10 \%$ & 10 & $15 \%$ & 25 & $37 \%$ & $\begin{array}{r}2.7 \\
0\end{array}$ & 1.61 \\
\hline \multirow[b]{5}{*}{ Value } & Q4 & $\begin{array}{l}\text { I like the interactive } \\
\text { activities }\end{array}$ & 52 & $78 \%$ & 6 & $9 \%$ & 6 & $9 \%$ & 2 & $3 \%$ & 1 & $1 \%$ & $\begin{array}{r}4.5 \\
8\end{array}$ & 0.88 \\
\hline & Q5 & $\begin{array}{l}\text { I think doing } \\
\text { interactive activities } \\
\text { is important in class } \\
\text { learning }\end{array}$ & 46 & $69 \%$ & 7 & $10 \%$ & 9 & $13 \%$ & 4 & $6 \%$ & 1 & $1 \%$ & $\begin{array}{r}4.3 \\
9\end{array}$ & 1.02 \\
\hline & Q6 & $\begin{array}{l}\text { I think interactive } \\
\text { activities helps my } \\
\text { learning }\end{array}$ & 48 & $72 \%$ & 10 & $15 \%$ & 5 & $7 \%$ & 2 & $3 \%$ & 2 & $3 \%$ & $\begin{array}{r}4.4 \\
9\end{array}$ & 0.97 \\
\hline & Q7 & $\begin{array}{l}\text { I wish I can do well } \\
\text { in interactive } \\
\text { activities }\end{array}$ & 38 & $57 \%$ & 8 & $12 \%$ & 11 & $16 \%$ & 4 & $6 \%$ & 6 & $9 \%$ & $\begin{array}{r}4.0 \\
1\end{array}$ & 1.33 \\
\hline & Q8 & $\begin{array}{l}\text { I think doing } \\
\text { interactive activity } \\
\text { is a waste of time. }\end{array}$ & 9 & $13 \%$ & 4 & $6 \%$ & 8 & $12 \%$ & 6 & $9 \%$ & 40 & $60 \%$ & $\begin{array}{r}2.0 \\
4\end{array}$ & 1.47 \\
\hline \multirow[b]{4}{*}{$\begin{array}{l}\text { Partici- } \\
\text { pation }\end{array}$} & Q9 & $\begin{array}{l}\text { I am willing to do } \\
\text { the interactive } \\
\text { activity }\end{array}$ & 37 & $55 \%$ & 10 & $15 \%$ & 16 & $24 \%$ & 1 & $1 \%$ & 3 & $4 \%$ & $\begin{array}{r}4.1 \\
5\end{array}$ & 1.11 \\
\hline & Q10 & $\begin{array}{l}\text { I fully participate in } \\
\text { interactive activities }\end{array}$ & 37 & $55 \%$ & 9 & $13 \%$ & 7 & $10 \%$ & 8 & $12 \%$ & 6 & $9 \%$ & $\begin{array}{r}3.9 \\
4 \\
\end{array}$ & 1.39 \\
\hline & Q11 & $\begin{array}{l}\text { I want to do the } \\
\text { interactive activities } \\
\text { the whole class }\end{array}$ & 21 & $31 \%$ & 15 & $22 \%$ & 18 & $27 \%$ & 6 & $9 \%$ & 7 & $10 \%$ & $\begin{array}{r}3.5 \\
5\end{array}$ & 1,30 \\
\hline & Q12 & $\begin{array}{l}\text { I want to do the } \\
\text { interactive activities } \\
\text { the partly in class }\end{array}$ & 39 & $58 \%$ & 11 & $16 \%$ & 7 & $10 \%$ & 4 & $6 \%$ & 6 & $9 \%$ & $\begin{array}{r}4.0 \\
9\end{array}$ & 1.31 \\
\hline
\end{tabular}


From these statistics in Table 4, we find that, under the Chinese education background, $88 \%$ of these students reported that they "wanted to do the interactive activities because [they] can learn happily." In fact, $87 \%$ of them reported that they either agree or very much agree with enjoying the interactive activity while $18 \%$ of them reported that they wanted to kill time because they were bored. Meanwhile, $37 \%$ of respondents said that they participated in interactive activities because they just follow teachers' orders. Interestingly, $79 \%$ of these students agreed that interactive activities are important in learning and $85 \%$ of them said that they think that interactive activities help their learning. From the sample, $70 \%$ of these students stated that they are willing to participate in interactive activities, while $68 \%$ of them believe that they were fully engaged in the activities and $69 \%$ of them said they wanted to perform well in interactive activities.

Negative voice towards interactive activities was also heard from those students. In fact, $19 \%$ of the students complained that interactive activities are a waste of time with $4 \%$ of them stating that they didn't like their interactive activities, and about $6 \%$ of them considering interactive activity as is neither important or helpful. A breakdown of these answers may be observed in Table 5 . 
Table 5. Degree of agreement according to survey questions.

\begin{tabular}{|c|c|c|}
\hline Attitudes & $\begin{array}{l}\text { Range of the } \\
\text { mean }\end{array}$ & Statements \\
\hline Very much agree & $4.50-5.00$ & $\begin{array}{l}\text { Q1: I want to do the interactive } \\
\text { activities because I can learn } \\
\text { happily } \\
\text { Q4: I like the interactive activities }\end{array}$ \\
\hline Agree & $3.50-4.49$ & $\begin{array}{l}\text { Q5: I think doing interactive } \\
\text { activities is important in class } \\
\text { learning } \\
\text { Q6: I think interactive activities } \\
\text { helps my learning } \\
\text { Q7: I wish I can do well in } \\
\text { interactive activities } \\
\text { Q9: I am willing to do the } \\
\text { interactive activity } \\
\text { Q10: I fully participate in } \\
\text { interactive activities } \\
\text { Q11: I want to do the interactive } \\
\text { activities the whole class } \\
\text { Q12: I want to do the interactive } \\
\text { activities the partly in class }\end{array}$ \\
\hline Unsure & $2.50-3.49$ & $\begin{array}{l}\text { Q3: I do the activity because the } \\
\text { teacher asks us to do }\end{array}$ \\
\hline Disagree & $1.50-2.49$ & $\begin{array}{l}\text { Q2: I want to do the interactive } \\
\text { activities because it kills the class } \\
\text { time } \\
\text { Q8: I think doing interactive activity } \\
\text { is a waste of time. }\end{array}$ \\
\hline Very much disagree & $0.00-1.49$ & \\
\hline
\end{tabular}

Therefore, from Table 5 we may conclude that the attitudes of the majority of the participants of the survey agreed that

1. they like the interactive activities;

2. the interactive activities are important and helpful, while creating a happy learning; and 
3. that they are willing to engage in interactive activities either for a whole class or partly in class.

The students seemed neutral about whether they would participate in the interactive activities as a result of teachers' orders. And the majority of the students didn't think interactive activities were waste of their time or accomplished simply just to kill time. On the other hand, a substantial number of respondents, on the order of a fifth of the students, stated that they didn't care much for interactive activities.

\section{Attitudes from boys and girls}

In this section, as shown in Table 6, I marked positive statements in green and negative statements in red. If there were more girls holding the positive attitudes, I marked the label in pink. If there were more boys holding positive attitudes, the label is blue. If no one checked the blank, it is gray.

From Tables 6 and 7, it is clear that data were collected from more girls than boys. In the data, $92 \%$ of the female participants in elementary school reported that they enjoy the interactive activity in the English class, and 94\% of the girls consider interactive activities can make them learn happily. From this data set, $80 \%$ of the boys stated that they hold similar opinions; however, this is at a clip $12 \%$ to $14 \%$ less than the that of female participants.

In Table 7 , we see that $86 \%$ of boys and girls agreed that interactive activities are helpful in English learning, and more girls thought that such activity brings significant influence in English learning than boys did. However, according to the data from Q7 
(question 7), $76 \%$ of the boys said they want to perform well in interactive activities whereas only $62 \%$ the girls had similar sentiments.

More negative voice was heard from boys than girls, as $40 \%$ of the boys said they think they do interactive activity when teachers tell them to. In fact, $20 \%$ of them have no interest in doing the activities at all, and $25 \%$ of them are unsure about why the activities are important. Furthermore, whether they want to participate or not, $27 \%$ stated that they don't think they have fully participated in interactive activities.

Table 6. Attitudes and labels.

\begin{tabular}{|l|l|l|l|l|l|}
\hline Attitudes: & $\begin{array}{l}\text { Positive } \\
\text { statement }\end{array}$ & $\begin{array}{l}\text { Negative } \\
\text { statement }\end{array}$ & $\begin{array}{l}\text { Positive Attitude from } \\
\text { boys }\end{array}$ & $\begin{array}{l}\text { Positive Attitude from } \\
\text { girls }\end{array}$ & No one's choice \\
\hline $\begin{array}{l}\text { Label } \\
\text { Color: }\end{array}$ & & & & & \\
\hline
\end{tabular}


Attitudes from boys and girls.

\begin{tabular}{|c|c|c|c|c|c|c|c|c|c|c|c|c|}
\hline \multirow[b]{3}{*}{ category } & & \multirow[b]{3}{*}{ Statement } & \multicolumn{10}{|c|}{ Boys $\mathrm{N}=30 \quad$ Girls $\mathrm{N}=37$} \\
\hline & & & \multicolumn{2}{|c|}{$\begin{array}{l}\text { very much } \\
\text { agree }\end{array}$} & \multicolumn{2}{|c|}{ agree } & \multicolumn{2}{|c|}{ unsure } & \multicolumn{2}{|c|}{ disagree } & \multicolumn{2}{|c|}{$\begin{array}{c}\text { very much } \\
\text { disagree }\end{array}$} \\
\hline & & & boys & girls & boys & girls & boys & girls & boys & girls & boys & girls \\
\hline \multirow[b]{3}{*}{$\begin{array}{l}\text { Moti- } \\
\text { vation }\end{array}$} & Q1 & $\begin{array}{l}\text { I want to do the } \\
\text { interactive activities } \\
\text { because I can learn } \\
\text { happily }\end{array}$ & $73 \%$ & $86 \%$ & $7 \%$ & $8 \%$ & $13 \%$ & $3 \%$ & & & $7 \%$ & $3 \%$ \\
\hline & Q2 & $\begin{array}{l}\text { I want to do the } \\
\text { interactive activities } \\
\text { because it kills the } \\
\text { class time }\end{array}$ & $13 \%$ & $5 \%$ & $7 \%$ & $11 \%$ & $7 \%$ & $11 \%$ & & $11 \%$ & $73 \%$ & $62 \%$ \\
\hline & Q3 & $\begin{array}{l}\text { I do the activity } \\
\text { because the teacher } \\
\text { asks us to do }\end{array}$ & $30 \%$ & $16 \%$ & $10 \%$ & $19 \%$ & $13 \%$ & $8 \%$ & $20 \%$ & $11 \%$ & $27 \%$ & $46 \%$ \\
\hline \multirow[b]{5}{*}{ Value } & Q4 & $\begin{array}{l}\text { I like the interactive } \\
\text { activities }\end{array}$ & $73 \%$ & $81 \%$ & $7 \%$ & $11 \%$ & $17 \%$ & $3 \%$ & $3 \%$ & $3 \%$ & & $3 \%$ \\
\hline & Q5 & $\begin{array}{l}\text { I think doing } \\
\text { interactive activities } \\
\text { is important in class } \\
\text { learning }\end{array}$ & $63 \%$ & $73 \%$ & $7 \%$ & $14 \%$ & $23 \%$ & $5 \%$ & $3 \%$ & $8 \%$ & $3 \%$ & \\
\hline & Q6 & $\begin{array}{l}\text { I think interactive } \\
\text { activities helps my } \\
\text { learning }\end{array}$ & $63 \%$ & $78 \%$ & $23 \%$ & $8 \%$ & $7 \%$ & $8 \%$ & & $5 \%$ & $7 \%$ & \\
\hline & Q7 & $\begin{array}{l}\text { I wish I can perform } \\
\text { well in interactive } \\
\text { activities }\end{array}$ & $63 \%$ & $51 \%$ & $13 \%$ & $11 \%$ & $17 \%$ & $16 \%$ & $7 \%$ & $5 \%$ & & $16 \%$ \\
\hline & Q8 & $\begin{array}{l}\text { I think doing } \\
\text { interactive activity is } \\
\text { a waste of time }\end{array}$ & $17 \%$ & $11 \%$ & $7 \%$ & $5 \%$ & $7 \%$ & $16 \%$ & $10 \%$ & $8 \%$ & $60 \%$ & $59 \%$ \\
\hline \multirow[b]{4}{*}{$\begin{array}{l}\text { Partici- } \\
\text { pation }\end{array}$} & Q9 & $\begin{array}{l}\text { I am willing to do the } \\
\text { interactive activity }\end{array}$ & $53 \%$ & $57 \%$ & $13 \%$ & $16 \%$ & $27 \%$ & $22 \%$ & & $3 \%$ & $7 \%$ & $3 \%$ \\
\hline & Q10 & $\begin{array}{l}\text { I fully participate in } \\
\text { interactive activities }\end{array}$ & $47 \%$ & $62 \%$ & $13 \%$ & $14 \%$ & $13 \%$ & $8 \%$ & $10 \%$ & $14 \%$ & $17 \%$ & $3 \%$ \\
\hline & Q11 & $\begin{array}{l}\text { I want to do the } \\
\text { interactive activities } \\
\text { the whole class }\end{array}$ & $33 \%$ & $30 \%$ & $13 \%$ & $30 \%$ & $33 \%$ & $22 \%$ & & $16 \%$ & $20 \%$ & $3 \%$ \\
\hline & Q12 & $\begin{array}{l}\text { I want to do the } \\
\text { interactive activities } \\
\text { the partly in class }\end{array}$ & $60 \%$ & $57 \%$ & $10 \%$ & $22 \%$ & $10 \%$ & $11 \%$ & $3 \%$ & $8 \%$ & $17 \%$ & $3 \%$ \\
\hline
\end{tabular}




\section{Attitudes from different ages}

In this part, as shown in Table 8 , I marked positive statements in green and negative statements in red. If there were more nine-year-old kids holding positive attitudes, the label is yellow. If there were more ten-year-old students holding positive attitudes, the label is orange. If there were more eleven-year-old students holding positive attitudes, the label is tan. If there were more twelve-year-old students holding positive attitudes, the label is dark brown. If no one checked anything, the blank is gray.

From the color label, we can find that the twelve-year-old students sported the most positive attitudes towards interactive activities. Such a finding suggests that they may feel relatively qualified to speak for this issue because they studied English at school for four years and have become more aware of the significance of interactive activities in assisting learning.

Interestingly, there is no color label for ten-year-old respondents. However, their attitudes towards interactive activities were generally positive with $79 \%$ of the supporters enjoying interactive activity in their English class. The data also show that $79 \%$ of these ten-year-olds admit that interactive activities are important, and $88 \%$ of them consider interactive activities as helpful as they can learn happily. Meanwhile, $75 \%$ of the tenyear-olds claimed that they were willing to the activity and wanted to perform well. 
Table 8. Attitudes \& labels.

\begin{tabular}{|c|c|c|c|c|c|c|c|}
\hline Attitudes: & $\begin{array}{l}\text { Positive } \\
\text { statement }\end{array}$ & $\begin{array}{l}\text { Negative } \\
\text { statement }\end{array}$ & $\begin{array}{l}\text { Positive } \\
\text { Attitude from } \\
9 \text { years old }\end{array}$ & $\begin{array}{l}\text { Positive } \\
\text { Attitude from } \\
10 \text { years old }\end{array}$ & $\begin{array}{l}\text { Positive } \\
\text { Attitude from } \\
11 \text { years old }\end{array}$ & $\begin{array}{l}\text { Positive } \\
\text { Attitude from } \\
12 \text { years old }\end{array}$ & $\begin{array}{l}\text { No one's } \\
\text { choice }\end{array}$ \\
\hline $\begin{array}{l}\text { Label } \\
\text { Color: }\end{array}$ & & & & & & & \\
\hline
\end{tabular}

Table 9. Attitudes by age.

\begin{tabular}{|c|c|c|c|c|c|c|}
\hline \multirow[b]{3}{*}{ Category } & \multirow{3}{*}{$\begin{array}{l}\text { Questio } \\
\text { n } \\
\text { code }\end{array}$} & \multirow[b]{3}{*}{ Questions } & \multicolumn{4}{|c|}{ Very much agree+agree } \\
\hline & & & $\begin{array}{l}9- \\
\text { year } \\
\text { olds }\end{array}$ & $\begin{array}{l}10- \\
\text { year } \\
\text { olds }\end{array}$ & $\begin{array}{l}11- \\
\text { year } \\
\text { olds }\end{array}$ & $\begin{array}{l}12- \\
\text { year } \\
\text { olds }\end{array}$ \\
\hline & & & $\%$ & $\%$ & $\%$ & $\%$ \\
\hline \multirow[b]{3}{*}{ Motivation } & Q1 & $\begin{array}{l}\text { I want to do the interactive } \\
\text { activities because I can learn } \\
\text { happily }\end{array}$ & $83 \%$ & $87 \%$ & $90 \%$ & $92 \%$ \\
\hline & Q2 & $\begin{array}{l}\text { I want to do the interactive } \\
\text { activities because it kills the class } \\
\text { time }\end{array}$ & $16 \%$ & $22 \%$ & $16 \%$ & $15 \%$ \\
\hline & Q3 & $\begin{array}{l}\text { I do the activity because the } \\
\text { teacher asks us to do }\end{array}$ & $50 \%$ & $43 \%$ & $32 \%$ & $23 \%$ \\
\hline \multirow[b]{5}{*}{ Value } & $\mathrm{Q} 4$ & I like the interactive activities & $91 \%$ & $78 \%$ & $90 \%$ & $93 \%$ \\
\hline & Q5 & $\begin{array}{l}\text { I think interactive activities is } \\
\text { important in class learning }\end{array}$ & $75 \%$ & $79 \%$ & $73 \%$ & $93 \%$ \\
\hline & Q6 & $\begin{array}{l}\text { I think interactive activities helps } \\
\text { my learning }\end{array}$ & $75 \%$ & $87 \%$ & $90 \%$ & $92 \%$ \\
\hline & Q7 & $\begin{array}{l}\text { I wish I can do well in interactive } \\
\text { activities }\end{array}$ & $75 \%$ & $74 \%$ & $64 \%$ & $62 \%$ \\
\hline & Q8 & $\begin{array}{l}\text { I think doing interactive activity is } \\
\text { a waste of time }\end{array}$ & $41 \%$ & $13 \%$ & $22 \%$ & $8 \%$ \\
\hline \multirow[b]{4}{*}{ Participation } & Q9 & $\begin{array}{l}\text { I am willing to do the interactive } \\
\text { activity }\end{array}$ & $50 \%$ & $74 \%$ & $79 \%$ & $69 \%$ \\
\hline & Q10 & $\begin{array}{l}\text { I fully participate in interactive } \\
\text { activities }\end{array}$ & $75 \%$ & $61 \%$ & $74 \%$ & $69 \%$ \\
\hline & Q11 & $\begin{array}{l}\text { I want to do the interactive } \\
\text { activities the whole class }\end{array}$ & $50 \%$ & $52 \%$ & $47 \%$ & $69 \%$ \\
\hline & Q12 & $\begin{array}{l}\text { I want to do the interactive } \\
\text { activities the partly in class }\end{array}$ & $75 \%$ & $69 \%$ & $90 \%$ & $62 \%$ \\
\hline
\end{tabular}


With respect to the notions that interactive activity may make people happy thereby helping students to learn, the eleven-year-olds' reporting was remarkably similar with that of the twelve-year-olds: $90 \%$ of the eleven-year-olds supported this idea, while $92 \%$ of the twelve-year-olds thought similarly.

\section{Comparison among ages}

The twelve-year-old participants held the highest rate for agreeing that interactive activity is happy learning - important in learning and helpful in learning. The elevenyear- olds showed the strongest willingness in doing the activities. The nine- and tenyear-olds were most ambitious at performing well in activities: $75 \%$ of the nine-year-olds claimed they could fully participant in activities, which is the highest among all the participants. Ambition with respect to performance starts to decline in terms of the attitudes expressed by eleven-year-olds, and this level achieves the lowest level with twelve-years-olds.

The data indicate that $69 \%$ of the twelve years thought that they are fully participant in the activities. With the pressure from the intensive learning in sixth grade, $69 \%$ of the participants still showed that they hope their teacher will implement interactive activities for the whole class - the highest support rate among all age groups.

One thing we need to notice is that, while a good proportion of nine-year-olds, $41 \%$, consider interactivity is a waste of time, among them, $16 \%$ would like to waste the time in class for killing the boringness in test-based learning, and $50 \%$ of the nine-yearolds would want their teacher to implement interactive activities for the whole time. 


\section{b. What, from elementary school students' perspective, might be the best teaching form in interactive activity to associate students' learning?}

To answer this question, the questionnaire designed questions 20 through 22 .

Results of students' answers pertaining to these questions are expressed in Table 10.

Table 10. Participants' perspective towards teaching tools

\begin{tabular}{|c|c|c|c|c|c|c|c|c|c|c|c|c|c|c|}
\hline \multirow{3}{*}{$\begin{array}{l}\text { Cate- } \\
\text { gory }\end{array}$} & \multirow[b]{3}{*}{ ? } & \multirow[b]{3}{*}{ questions } & \multicolumn{10}{|c|}{ All students $\mathrm{N}=67$} & & \\
\hline & & & \multicolumn{2}{|c|}{$\begin{array}{l}\text { very much } \\
\text { agree }\end{array}$} & \multicolumn{2}{|c|}{ agree } & \multicolumn{2}{|c|}{ unsure } & \multicolumn{2}{|c|}{ disagree } & \multicolumn{2}{|c|}{$\begin{array}{c}\text { very } \\
\text { much } \\
\text { disagree }\end{array}$} & & \\
\hline & & & $\mathrm{N}$ & $\%$ & $\mathrm{~N}$ & $\%$ & $\mathrm{~N}$ & $\%$ & $\mathrm{~N}$ & $\%$ & $\mathrm{~N}$ & $\%$ & Mean & SD \\
\hline & Q20 & $\begin{array}{l}\text { I like the activities } \\
\text { with music }\end{array}$ & 35 & $52 \%$ & 16 & $24 \%$ & 8 & $12 \%$ & 4 & $6 \%$ & 4 & $6 \%$ & 4.10 & 1.19 \\
\hline & Q21 & $\begin{array}{l}\text { I like the activities } \\
\text { with pictures and } \\
\text { videos }\end{array}$ & 47 & $70 \%$ & 13 & $19 \%$ & 3 & $4 \%$ & 2 & $3 \%$ & 2 & $3 \%$ & 4.50 & 0.94 \\
\hline Forms & $\mathrm{O} 22$ & $\begin{array}{l}\text { I like the } \\
\text { interactive } \\
\text { activities with } \\
\text { competitions and } \\
\text { awards }\end{array}$ & 47 & $70 \%$ & 11 & $16 \%$ & 6 & $9 \%$ & 1 & $1 \%$ & 2 & $3 \%$ & 4.49 & 0.94 \\
\hline
\end{tabular}

Table 11. Degree of agreement according to survey questions-part 2

\begin{tabular}{|l|l|l|}
\hline Attitudes & $\begin{array}{l}\text { Range of the } \\
\text { mean }\end{array}$ & Statements \\
\hline Very much agree & $4.50-5.00$ & $\begin{array}{l}\text { Q21: I like the activities with } \\
\text { pictures and videos }\end{array}$ \\
\hline Agree & $3.50-4.49$ & $\begin{array}{l}\text { Q20: I like the activities with music } \\
\text { Q22: I like the interactive activities } \\
\text { with competitions and awards }\end{array}$ \\
\hline Unsure & $2.50-3.49$ & \\
\hline Disagree & $1.50-2.49$ & \\
\hline Very much disagree & $0.00-1.49$ & \\
\hline
\end{tabular}

From Tables 10 and 11, we find that all students reported liking verbal and visual tools in assisting their leaning. Within the data, we see that $76 \%$ of the students said they like activities with music (verbal tools), $89 \%$ of them like pictures and videos (video tools), and $86 \%$ of them like the activities with competitions and awards. 


\section{c. What types of instruction seem to be more acceptable for elementary school students when implementing interactive activities?}

To answer this question, the questionnaire was composed with questions 13

through 17. Data corresponding to respondents' answers for these questions are displayed in Table 12.

Table 12. Participants' perspectives towards teachers' instruction

\begin{tabular}{|c|c|c|c|c|c|c|c|c|c|c|c|c|c|c|}
\hline \multirow{3}{*}{$\begin{array}{c}\text { Categor } \\
y\end{array}$} & \multirow[b]{3}{*}{ ? } & \multirow[b]{3}{*}{ questions } & \multicolumn{10}{|c|}{ All students $\mathrm{N}=67$} & \multirow[b]{3}{*}{ Mean } & \multirow[b]{3}{*}{ SD } \\
\hline & & & \multicolumn{2}{|c|}{$\begin{array}{l}\text { very much } \\
\text { agree }\end{array}$} & \multicolumn{2}{|c|}{ agree } & \multicolumn{2}{|c|}{ unsure } & \multicolumn{2}{|c|}{ disagree } & \multicolumn{2}{|c|}{$\begin{array}{l}\text { very much } \\
\text { disagree }\end{array}$} & & \\
\hline & & & $\mathrm{N}$ & $\%$ & $\mathrm{~N}$ & $\%$ & $\mathrm{~N}$ & $\%$ & $\mathrm{~N}$ & $\%$ & $\mathrm{~N}$ & $\%$ & & \\
\hline & Q13 & $\begin{array}{l}\text { I prefer the teacher } \\
\text { instruct in only } \\
\text { Chinese language }\end{array}$ & 17 & $25 \%$ & 12 & $18 \%$ & 18 & $27 \%$ & 9 & $13 \%$ & 11 & $16 \%$ & 3.22 & 1.39 \\
\hline & Q14 & $\begin{array}{l}\text { I prefer the teacher } \\
\text { instruct in only } \\
\text { English language }\end{array}$ & 23 & $34 \%$ & 20 & $30 \%$ & 12 & $18 \%$ & 7 & $10 \%$ & 5 & $7 \%$ & 3.73 & 1.24 \\
\hline & Q15 & $\begin{array}{l}\text { I hope the teacher } \\
\text { can use both } \\
\text { English and } \\
\text { Chinese in } \\
\text { instruction }\end{array}$ & 36 & $54 \%$ & 19 & $28 \%$ & 8 & $12 \%$ & 3 & $4 \%$ & 1 & $1 \%$ & 4.28 & 0.94 \\
\hline & Q16 & $\begin{array}{l}\text { I can understand } \\
\text { the teacher if } \\
\text { she/he uses the } \\
\text { English instruction } \\
\text { with body } \\
\text { language }\end{array}$ & 37 & $55 \%$ & 15 & $22 \%$ & 6 & $9 \%$ & 5 & $7 \%$ & 4 & $6 \%$ & 4.13 & 1.21 \\
\hline $\begin{array}{l}\text { Instruc- } \\
\text { tion }\end{array}$ & Q17 & $\begin{array}{l}\text { I can understand } \\
\text { the teacher if } \\
\text { she/he uses the } \\
\text { English instruction } \\
\text { with body } \\
\text { language and } \\
\text { examples }\end{array}$ & 38 & $57 \%$ & 17 & $25 \%$ & 6 & $9 \%$ & 3 & $4 \%$ & 3 & $4 \%$ & 4.25 & 1.08 \\
\hline
\end{tabular}

From the perspective of these Chinese elementary school students who participated in the survey, Table 12 shows that $82 \%$ of the them said that they support teachers in English class using both Chinese and English languages, and a similar quantity of students agreed that they can understand teachers if they conduct English instruction with body language and examples. The $82 \%$ mark was the highest proportion expressed among varying instruction practices. In the meantime, $64 \%$ of the participants 
said that they prefer that their teacher use only English for instruction, while $77 \%$ of the students agreed that their teacher successfully uses English instruction and body language and that such practice is helpful.

Table 13 reflects that the majority of the participants are not sure about whether it is a good idea that English teacher speak only Chinese for instruction in activities.

Indeed, the majority of the students agreed with the idea that teachers should be speaking English in class, but respondents' attitudes differed when it comes to how teachers speak it and how much they speak it.

Table 13. Degree of agreement according to survey questions-part 3

\begin{tabular}{|c|c|c|}
\hline Attitudes & $\begin{array}{l}\text { Range of the } \\
\text { mean }\end{array}$ & Statements \\
\hline Very much agree & $4.50-5.00$ & \\
\hline Agree & $3.50-4.49$ & $\begin{array}{l}\text { Q14: I prefer the teacher instruct in } \\
\text { only Chinese language } \\
\text { Q15: I hope the teacher can use } \\
\text { both English and Chinese in } \\
\text { instruction } \\
\text { Q16: I can understand the teacher if } \\
\text { she/he uses the English instruction } \\
\text { with body language } \\
\text { Q17: I can understand the teacher if } \\
\text { she/he uses the English instruction } \\
\text { with body language and examples }\end{array}$ \\
\hline Unsure & $2.50-3.49$ & $\begin{array}{l}\text { Q13: I prefer the teacher instruct in } \\
\text { only Chinese language }\end{array}$ \\
\hline Disagree & $1.50-2.49$ & \\
\hline Very much disagree & $0.00-1.49$ & \\
\hline
\end{tabular}




\section{d. To what extent do Chinese teachers handle problems and give revision in class?}

I was interested in how students might answer this question. As a result, I placed two questions - Q18 and Q19 - into the survey. The results regarding how students answered these questions are demonstrated in Table 14.

Table 14. Participants' perspective towards teachers' revision

\begin{tabular}{|c|c|c|c|c|c|c|c|c|c|c|c|c|c|c|}
\hline \multirow{3}{*}{$\begin{array}{l}\text { Cate- } \\
\text { gory }\end{array}$} & \multirow[b]{3}{*}{ ? } & \multirow[b]{3}{*}{ questions } & \multicolumn{10}{|c|}{ All students $\mathrm{N}=67$} & & \\
\hline & & & \multicolumn{2}{|c|}{$\begin{array}{l}\text { very much } \\
\text { agree }\end{array}$} & \multicolumn{2}{|c|}{ agree } & \multicolumn{2}{|c|}{ unsure } & \multicolumn{2}{|c|}{ disagree } & \multicolumn{2}{|c|}{$\begin{array}{c}\text { very much } \\
\text { disagree }\end{array}$} & & \\
\hline & & & $\mathrm{N}$ & $\%$ & $\mathrm{~N}$ & $\%$ & $\mathrm{~N}$ & $\%$ & $\mathrm{~N}$ & $\%$ & $\mathrm{~N}$ & $\%$ & Mean & SD \\
\hline & Q18 & $\begin{array}{l}\text { Teachers often } \\
\text { handle the } \\
\text { problem occurred } \\
\text { in activities }\end{array}$ & 47 & $70 \%$ & 10 & $15 \%$ & 7 & $10 \%$ & 2 & $3 \%$ & 1 & $1 \%$ & 4.49 & 0.90 \\
\hline $\begin{array}{c}\text { Revi- } \\
\text { sion }\end{array}$ & Q19 & $\begin{array}{l}\text { Teachers often } \\
\text { give discussion } \\
\text { and feedback after } \\
\text { the activities }\end{array}$ & 45 & $67 \%$ & 8 & $12 \%$ & 9 & $13 \%$ & 3 & $4 \%$ & 2 & $3 \%$ & 4.36 & 1.06 \\
\hline
\end{tabular}

From Table 14 we find that the majority of Chinese elementary school students reported that they think teachers often discuss and give feedback after activities. They also report that teachers are able to deal with problems occurring during these activities.

The statistics suggest that $85 \%$ of the participants agreed that their English teachers are able to handle problems occurring in interactive activities. The survey showed, in factm that $79 \%$ of them said their teachers often give discussion and feedback to students after the activities. However, there are still $4 \%$ of the students who don't believe that their teachers can maintain activities in a smooth fashion, and $7 \%$ of the students reflected that their teachers never give discussion and feedback after an activity. 


\section{What is the influence of interactive teaching in EFL classes on the development of}

elementary aged Chinese students, both academically and socially?

\section{a. To what extent are students and teachers satisfied with interactive activities?}

To address this issue the survey included question 23 through 29. Respondents' answers to these questions are shown in Table 15.

Table 15. Teachers and participants' satisfaction of interactive activities

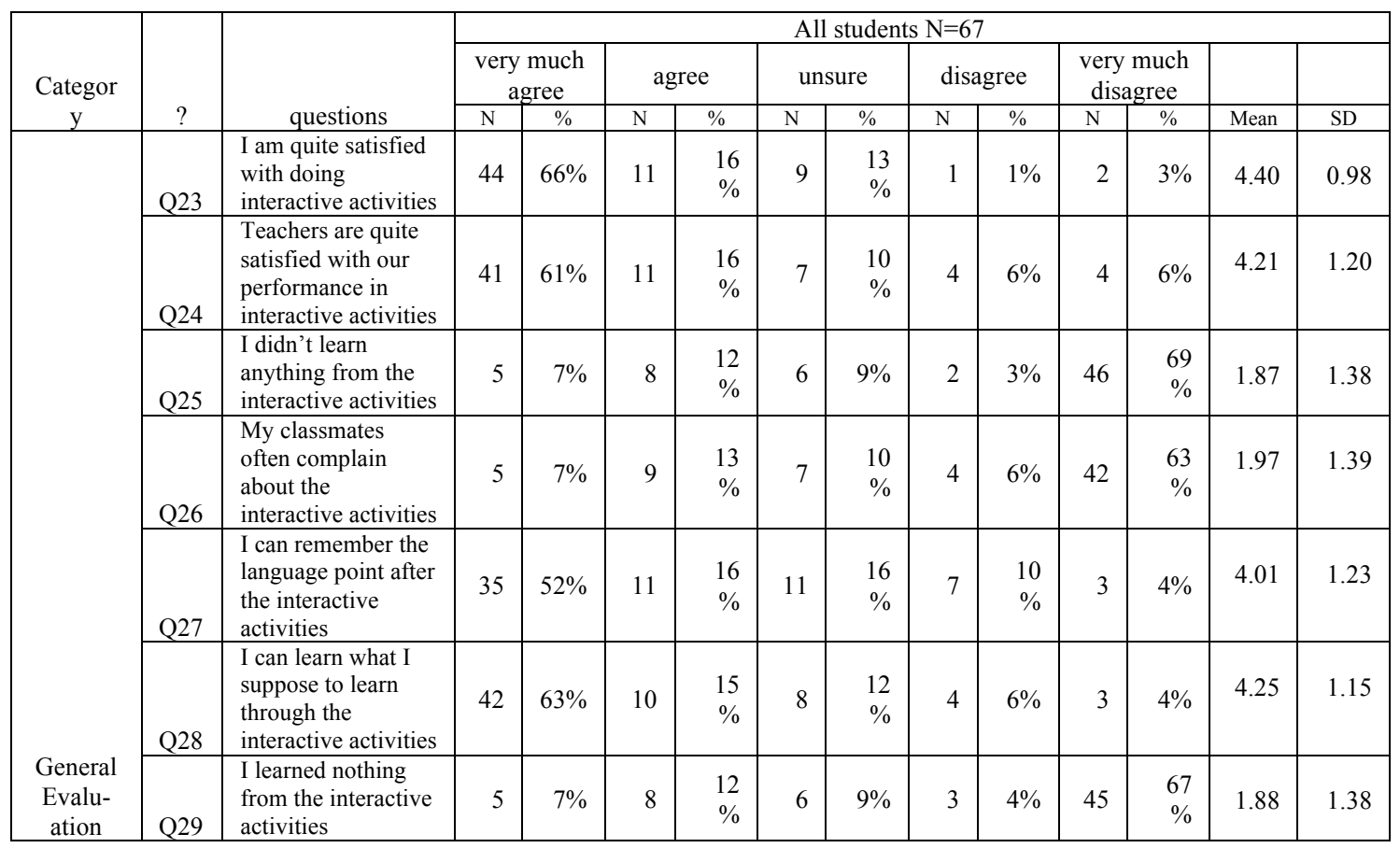

In Table 15, we find degrees of student satisfaction with respect to interactive activities in English class assembly. Table 15 shows that $82 \%$ of respondents indicated are satisfaction with interactive activities, and $78 \%$ of them found that their teachers are satisfied with their performance. It additionally shows that $78 \%$ of these participants agree that they learned what they were supposed to learn in classes involving interactive 
activities, and $68 \%$ said they can remember key language points after having studied via the use of interactive activities.

Negative voices also were also evident in the data as $19 \%$ of these students said they learned nothing from the interactive activities. In fact, $9 \%$ of them were not sure if they learned anything. Additionally, $20 \%$ of these participants claimed that they often hear complaints about the interactive activities from their classmates.

A synopsis of these comments may be observed in Table 16.

Table 16. Degree of agreement according to survey questions-part 4

\begin{tabular}{|l|l|l|}
\hline Attitudes & $\begin{array}{l}\text { Range of the } \\
\text { mean }\end{array}$ & Statements \\
\hline Very much agree & $4.50-5.00$ & Q23: I am quite satisfied with doing \\
\hline Agree & $3.50-4.49$ & $\begin{array}{l}\text { Q23 } \\
\text { interactive activities } \\
\text { Q24: Teachers are quite satisfied } \\
\text { with our performance in interactive } \\
\text { activities } \\
\text { Q27: I can remember the language } \\
\text { point after the interactive activities } \\
\text { Q28: I can learn what I suppose to } \\
\text { learn through the interactive } \\
\text { activities }\end{array}$ \\
\hline Unsure & $\begin{array}{l}\text { Q25: I didn't learn anything from } \\
\text { the interactive activities } \\
\text { Q26: My classmates often complain } \\
\text { about the interactive activities } \\
\text { Q29: I learned nothing from the } \\
\text { interactive activities }\end{array}$ \\
\hline Disagree & $2.50-3.49$ & \\
\hline Very much disagree & $1.50-2.49$ & \\
\hline
\end{tabular}




\section{b. How might interactive activity help students improve scores on traditional English tests?}

In addressing this question, questions 30 to 32 were implemented within the questionnaire. A statistical synopsis of respondents' answers to those questions is included in Table 17.

Table 17. Participants' evaluation of their performance in traditional tests

\begin{tabular}{|c|c|c|c|c|c|c|c|c|c|c|c|c|c|c|}
\hline \multirow[b]{3}{*}{$\begin{array}{l}\text { Cate- } \\
\text { gory }\end{array}$} & \multirow[b]{3}{*}{$?$} & \multirow[b]{3}{*}{ questions } & \multicolumn{12}{|c|}{ All students $\mathrm{N}=67$} \\
\hline & & & \multicolumn{2}{|c|}{$\begin{array}{c}\text { very much } \\
\text { agree }\end{array}$} & \multicolumn{2}{|c|}{ agree } & \multicolumn{2}{|c|}{ unsure } & \multicolumn{2}{|c|}{ disagree } & \multicolumn{2}{|c|}{$\begin{array}{l}\text { very much } \\
\text { disagree }\end{array}$} & \multirow[b]{2}{*}{$\begin{array}{c}\text { Mea } \\
n\end{array}$} & \multirow[b]{2}{*}{$\mathrm{SD}$} \\
\hline & & & $\mathrm{N}$ & $\%$ & $\mathrm{~N}$ & $\%$ & $\mathrm{~N}$ & $\%$ & $\mathrm{~N}$ & $\%$ & $\mathrm{~N}$ & $\%$ & & \\
\hline & $\begin{array}{l}\text { Q } \\
30\end{array}$ & $\begin{array}{l}\text { I do well in the } \\
\text { interactive activities, } \\
\text { and I get good test } \\
\text { scores. }\end{array}$ & 35 & $52 \%$ & 14 & $21 \%$ & 12 & $18 \%$ & 2 & $\begin{array}{r}3 \\
\%\end{array}$ & 4 & $6 \%$ & 4.10 & $\begin{array}{r}1.3 \\
5\end{array}$ \\
\hline & $\begin{array}{l}\mathrm{Q} \\
31\end{array}$ & $\begin{array}{l}\text { I do well in the } \\
\text { interact activities and } \\
\text { it improve my test } \\
\text { scores. }\end{array}$ & 42 & $63 \%$ & 11 & $16 \%$ & 10 & $15 \%$ & 1 & $\begin{array}{r}1 \\
\%\end{array}$ & 3 & $4 \%$ & 4.31 & $\begin{array}{r}1.0 \\
6\end{array}$ \\
\hline $\begin{array}{l}\text { Aca- } \\
\text { demic }\end{array}$ & $\begin{array}{l}\mathrm{Q} \\
32\end{array}$ & $\begin{array}{l}\text { I do well in the } \\
\text { interactive activities } \\
\text { even though my test } \\
\text { score doesn't } \\
\text { improve, my } \\
\text { listening and } \\
\text { speaking skills are } \\
\text { improved }\end{array}$ & 23 & $34 \%$ & 15 & $22 \%$ & 15 & $22 \%$ & 4 & $\begin{array}{r}6 \\
\%\end{array}$ & 10 & $15 \%$ & 3.55 & $\begin{array}{r}1.4 \\
0\end{array}$ \\
\hline
\end{tabular}

In Table 17, the standard deviations are small, and the means are in the range of agreement. This result suggests that, from the perspectives of the participants, that students perceive that the interactive activities have been promoting their academic development. To this end,79\% of the participants reported that the activities improve their test scores. Additionally, $73 \%$ of these students thought they did well in interactive activities, and they had good test scores. Finally, $56 \%$ of the participants said that even though the test results hadn't improved, they felt that their listening and speaking skills had improved. 
Still, some students suggested otherwise. A number of respondents indicated that they felt that interactive activities hadn't promoted their academic development: $9 \%$ of the students thought they neither perform well in the activities nor achieve good test scores. The data also indicate that $18 \%$ of the students demonstrated doubt about interactive activities with respect to improving their achievement on tests, and 5\% confirmed that their test results failed to improve even though they felt they performed well with interactive activities. Finally, $44 \%$ of these students either disagreed or felt unsure about how interactive activities improved their test scores or, more concretely, developed their English listening and speaking skills.

\section{c. To what extent might interactive activity help raise students' learning ability and confidence and assist in their motivation?}

To address this question, a set of nine questions was established within the questionnaire. The results regarding participants' answers are shown in Table 18.

From Table 18, we find points regarding interactive activities and their possible contribution to students' emotion and social development. Notably, students' attitudes are quite positive. No subject strongly disagreed with the idea that interactive activities guide their learning.

Optimistically, in Table 18, we discover that more than $70 \%$ of the students support all the positive statements about interactive activities in terms of making them confident, socialized, and talkative. The results also indicate enhanced friendships, relationship between students and parents, as well as students and teachers. The results show that $76 \%$ of the participants said they made more friends by interactive activities, 
with $73 \%$ of them saying they had more confidence because of the interactive activity, $78 \%$ of them claiming that they know how to learn well by doing the interactive activities, and $79 \%$ of the participants agreeing that interactive activities motivate them to live well socially. The results indicated that $81 \%$ of these students said interactive activities improved their relationship with teachers. A full $82 \%$ of them indicated that teachers were sharing fun stories happened within the activities that ultimately were shared with their parents, and $74 \%$ of them said that they shared the what they learned in the activities with their parents.

A synopsis of these results, question by question, may be observed in Table 19 . 
Table 18. Participants' perspective of self-improvement from interactive activities

\begin{tabular}{|c|c|c|c|c|c|c|c|c|c|c|c|c|c|c|}
\hline \multirow{3}{*}{$\begin{array}{l}\text { Cate- } \\
\text { gory }\end{array}$} & \multirow[b]{3}{*}{$?$} & \multirow[b]{3}{*}{ questions } & \multicolumn{10}{|c|}{ All students $\mathrm{N}=67$} & \multirow[b]{3}{*}{ mean } & \multirow[b]{3}{*}{ SD } \\
\hline & & & \multicolumn{2}{|c|}{$\begin{array}{c}\text { very much } \\
\text { agree }\end{array}$} & \multicolumn{2}{|c|}{ agree } & \multicolumn{2}{|c|}{ unsure } & \multicolumn{2}{|c|}{ disagree } & \multicolumn{2}{|c|}{$\begin{array}{c}\text { very much } \\
\text { disagree }\end{array}$} & & \\
\hline & & & $\mathrm{N}$ & $\%$ & $\mathrm{~N}$ & $\%$ & $\mathrm{~N}$ & $\%$ & $\mathrm{~N}$ & $\%$ & $\mathrm{~N}$ & $\%$ & & \\
\hline & Q33 & $\begin{array}{l}\text { I have made more } \\
\text { friends by } \\
\text { interactive } \\
\text { activities }\end{array}$ & 39 & $58 \%$ & 12 & $18 \%$ & 9 & $13 \%$ & 4 & $6 \%$ & 3 & $4 \%$ & 4.19 & 1.15 \\
\hline & Q34 & $\begin{array}{l}\text { I become more } \\
\text { confident by doing } \\
\text { the interactive } \\
\text { activities }\end{array}$ & 38 & $57 \%$ & 11 & $16 \%$ & 9 & $13 \%$ & 6 & $9 \%$ & 3 & $4 \%$ & 4.12 & 1.20 \\
\hline & Q35 & $\begin{array}{l}\text { I become more } \\
\text { confident to do } \\
\text { speech and } \\
\text { presentations }\end{array}$ & 33 & $49 \%$ & 15 & $22 \%$ & 7 & $10 \%$ & 10 & $15 \%$ & 2 & $3 \%$ & 4.00 & 1.21 \\
\hline & Q36 & $\begin{array}{l}\text { I become more } \\
\text { confident in } \\
\text { communicating } \\
\text { and negotiating } \\
\text { we people }\end{array}$ & 32 & $48 \%$ & 8 & $12 \%$ & 15 & $22 \%$ & 9 & $13 \%$ & 3 & $4 \%$ & 3.85 & 1.27 \\
\hline & Q37 & $\begin{array}{l}\text { I know how to } \\
\text { learn well by } \\
\text { doing the } \\
\text { interactive } \\
\text { activities } \\
\end{array}$ & 40 & $60 \%$ & 12 & $18 \%$ & 11 & $16 \%$ & 4 & $6 \%$ & & & 4.31 & 0.95 \\
\hline & Q38 & $\begin{array}{l}\text { The interactive } \\
\text { activities motivate } \\
\text { me to live well in } \\
\text { social life }\end{array}$ & 45 & $67 \%$ & 8 & $12 \%$ & 12 & $18 \%$ & 1 & $1 \%$ & 1 & $1 \%$ & 4.42 & 0.93 \\
\hline & Q39 & $\begin{array}{l}\text { The interactive } \\
\text { activities } \\
\text { improved my } \\
\text { relationship with } \\
\text { teachers }\end{array}$ & 42 & $63 \%$ & 12 & $18 \%$ & 8 & $12 \%$ & 3 & $4 \%$ & 2 & $3 \%$ & 4.33 & 1.04 \\
\hline & Q40 & $\begin{array}{l}\text { I often share the } \\
\text { fun stories } \\
\text { happened in the } \\
\text { activities with my } \\
\text { parents. }\end{array}$ & 49 & $73 \%$ & 6 & $9 \%$ & 9 & $13 \%$ & & & 3 & $4 \%$ & 4.46 & 1.03 \\
\hline $\begin{array}{l}\text { Social/ } \\
\text { Emo- } \\
\text { tional }\end{array}$ & Q41 & $\begin{array}{l}\text { I often share the } \\
\text { what I learn in the } \\
\text { activities with my } \\
\text { parents. }\end{array}$ & 43 & $64 \%$ & 7 & $10 \%$ & 12 & $18 \%$ & 1 & $1 \%$ & 4 & $6 \%$ & 4.25 & 1.16 \\
\hline
\end{tabular}


Table 19. Degree of agreement according to survey questions-part 5

\begin{tabular}{|c|c|c|}
\hline Perspectives & $\begin{array}{l}\text { Range of the } \\
\text { mean }\end{array}$ & Statements \\
\hline Very much agree & $4.50-5.00$ & \\
\hline Agree & $3.50-4.49$ & $\begin{array}{l}\text { Q33: I have made more friends by } \\
\text { interactive activities } \\
\text { Q34: I become more confident by } \\
\text { doing the interactive activities } \\
\text { Q35: I become more confident to do } \\
\text { speech and presentations } \\
\text { Q36: I become more confident in } \\
\text { communicating and negotiating we } \\
\text { people } \\
\text { Q37: I know how to learn well by } \\
\text { doing the interactive activities } \\
\text { Q38: The interactive activities } \\
\text { motivate me to live well in social } \\
\text { life } \\
\text { Q39: The interactive activities } \\
\text { improved my relationship with } \\
\text { teachers } \\
\text { Q40: I often share the fun stories } \\
\text { happened in the activities with my } \\
\text { parents. } \\
\text { Q41: I often share the what I learn } \\
\text { in the activities with my parents }\end{array}$ \\
\hline Unsure & $2.50-3.49$ & \\
\hline Disagree & $1.50-2.49$ & \\
\hline Very much disagree & $0.00-1.49$ & \\
\hline
\end{tabular}




\section{CHAPTER V}

\section{DISCUSSION}

\section{Findings}

\section{Attitudes from different age $\&$ genders}

From the following statistics we find that, under the Chinese education background, a majority of the Chinese students like the interactive activities, but the reasons of the students' participation are different, some of them fully enjoy it, some of them want to kill time in boring learning and some of them just flow with teachers' orders. Complaints about the interactivities can be heard as it is a waste of time.

Girls have the tendency to be more positive and engaging in the interactive activities than boys. While boys tend to feel more confused when doing the activities. However, they inclined to be more aggressive and ambitious than girls in performing well in interactive activities.

Twelve-year-old students hold the most positive attitudes towards interactive activities. The group of eleven-year-olds and the twelve-year-olds are both strongly support that idea that interactive activities make people happy and help students learn. The twelve-year-olds hold the highest rate for agreeing that interactive activity is happy learning, important in learning and helpful in learning. The eleven-year-olds have the strongest willingness in doing the activities. The ten- and nine-year-olds seem to be most forthright at wishing to perform well in these activities.

The attitudes of ten-year-olds toward interactive activities are generally positive, albeit without the enthusiasm demonstrated by respondents of other ages. The data 
showed, remarkably, that the nine-year-olds were the group that most fervently considered interactive activities a waste of time, albeit the majority of nine-year-olds still resonated positively with such in-class design.

\section{The most preferred teaching tools}

From the perspective of the Chinese children, using visual tools were reported to be the best way in assisting learning. Visual tools were shown most appreciation, with competition and awards coming second, followed by music.

\section{Instruction}

The majority of the Chinese student participants reported that they actually hope their teachers speak both Chinese and English languages in English classes. There is also evidence from the questionnaire to suggest that if teachers rely exclusively on English in instruction, students prefer having numerous examples and teachers implementing body languages so that they may understand.

\section{Revision}

Most of the participants stated that they believe their English teachers in China are able to handle the problem in interactive activities. They also stated that teachers arrange discussion time and give feedback to students after the activities. In other words, given an anonymous survey, the majority of students expressed appreciation for the assessment techniques of their teachers. 


\section{Academic achievement}

Regarding the participants, interactive activities seemingly helps a fair number of students but certainly not all. While a slight majority of students responded positively with respect to connecting interactive activities to their academic achievement, a viable number of respondents claimed that interactive activities won't always help their English learning. Approximately $20 \%$ of the students suggest that they didn't learn anything, and $10 \%$ of the them consider that they neither perform well in the activities nor achieve good test scores. Some were concerned that they didn't learn what they supposed to learn and they can't remember grammar points after the activities.

\section{Emotional and social development}

The majority of the students admit interactive activities make them confident, socialized, and talkative. They believe interactive activities enhanced their friendships and build up their relationships with parents and teachers. Interactive activity may not be a great tool to help Chinese students get a beautiful test score, but these students' answers suggest that such activity is definitely one of the best ways to develop their mental health. Perhaps most importantly, the responses to the questionnaire indicate that interactive activities seem to play a role in students' development in social skills, not only by advancing their friendships with schools but assisting with their relationships with their families. 


\section{Limitations and implications for further research}

No data collection pertaining to specific interactive activity approaches like taskbased language teaching (TBLT) or other specific approaches were a part of this study. Teachers dedicated to well-chronicled teaching approaches may wish to perform specific questionnaires regarding students' perspectives toward them.

Data regarding the degree to which students say they use higher order thinking while participating in interactive activities were not reported in this study. Future examinations of data can look into the degrees to which students have a sense of their own metacognitive processes.

Similarly, no observation techniques were undertaken as part of this study. In other words, examining these participants as they work through actual interactive activities was not within the purview of this thesis. Qualitative inquiry in pursuit of possible triangulation of these data could yield deeper results that indicate degrees of usefulness of ESOL-friendly techniques in Chinese contexts.

Notably, the sample of the survey was smaller than hoped. While the sample size was mostly satisfying, the goal of 100 respondents was not achieved.

Additionally, this study took place exclusively a tier two city in China. The data here may not be generalizable to metropolitan areas like Beijing, Shenzhen, or Shanghai where education is considered more advanced and internationalized. On the other hand, most people in China don't have the chance to get the best education. Most of the people are living in the tier two cities in China; therefore, data collected from tier two cities might actually be considered more representative of the general Chinese public. 
Finally, students' learning of new cultures was not a consideration expressed within the questionnaire. Future studies could include considerations regarding how interactive activities in English class might help students open a global vision and understand the culture of the rest of the world. 


\section{REFERENCES}

Atkinson, D. (1987). The mother tongue in the classroom: A neglected resource? ELT Journal 41 (4): 241-247.

Algonquin College of Applied Arts. (n.d.). Interactive Lessons \& Review Activities. Retrieved 2019 from https://www.algonquincollege.com/lts/interactive-learningactivities/.

ARMA International Center for Education (n.d.). Retrieved 2019 from https://magazine.arma.org/.

Auerbach, E.R. (1993). Reexamining English Only in the ESL Classroom. TESOL Quarterly 27 (1): 9-32.

Brown, G., \& Yule, G. (1983). Teaching the spoken language. Cambridge: Cambridge University Press.

Brown, H.D. (2007). Principles of language learning and teaching. White Plains, NY: Pearson ESL.

Boggs, J.G., Mickel, A.E., \& Holtom, B.C. (2007). Experiential Learning Through Interactive Drama: An Alternative To Student Role Plays Journal of Management Education 31 (6): 832-858. DOI: 10.1177/1052562906294952.

Brophy, J. (2010). Motivating students to learn. Mahwah, NJ: Lawrence Ehlbaum Associates, Publishers.

Bu, Y., \& Li, J. (2013). The New Basic Education and Whole School Reform: a Chinese experience. Frontiers of Education in China, 4, 576-595.

Britt, S., Wilkins, J., Davis, J., \& Bowlin, A. (2017). The Benefits of Interactive ReadAlouds to Address Social-Emotional Learning in Classrooms for Young Children, Journal of Character Education.

Cavanaugh, M. (2011). Students' experiences of active engagement through cooperative learning activities in lectures. Active Learning in Higher Education, 12, 23-33.

Cook, V. (2008). Second Language Learning and Language Teaching. 4th Ed. London: Arnold.

Cook, V. (2016). Second language learning and language. $5^{\text {th }}$ Ed. New York: Routledge.

Cambridge dictionary (n.d.) Retrieved 2020 from https://dictionary.cambridge.org/us/. 
Department for Education (2014). Statutory Guidance Early Years Foundation Stage (EYFS). Retrieved 2019 from https://www.gov.uk/government/publications/earlyyears-foundation-stage-framework--2.

Dewey, J., \& Dewey, E. (1915/1980) Schools of tomorrow. In J. A. Boydston (Ed.) John Dewey: The Middle Works (1899-1924) (vol. 8) (Carbondale, Southern Illinois Press), 5-404.

Ellis, R., \& He, X. (1999). The roles of modified input and output in the incidental acquisition of word meanings. Studies in Second Language Acquisition, 21(2), 285-301.

Eccles, J.S., Fredricks, J.A., \& Baay, P. (2015). Expectancies, Values, Identities, and Self-regulation. Cambridge: Cambridge University Press.

Gentry, J.W. (1990). Guide to business gaming and experiential learning. East Brunswick: Nichols/GP Pub.

Galloway, A. (1993). Communicative Language Teaching: An Introduction and Sample Activities. The Definition Of The Flipped Classroom. (2016, March 04). Retrieved 2019 from https://www.teachthought.com/learning/the-definition-ofthe-flipped-classroom/.

Gass, S. (1997). Input, interaction and the second language learner. Mahwah, NJ: Lawrence Erlbaum.

Gardner, B., \& Gardner, F. (2000). Classroom English. Cambridge: Cambridge University Press.

Gu, H., Yin, L., \& Li, J. (2015). Making Homework a Catalyst of Teacher-ParentsChildren's Collaboration: A Teacher Research Study from an Elementary School in China. International Journal about Parents in Education. 9(1): 47-65.

Giorgdze, M. \& Dgebuadze, M. (2017). Interactive Teaching Method: Challenge and Perspectives. International E-Journal of Advances in Education.

Hatch, E. (1978). Acquisition of syntax in a second language. In J. Richards (Ed.), Understanding second and foreign language learning (pp. 34-70). Rowley, MA: Newbury House.

Hubley, J. (1993). Communicating Health. London: Macmillan.

Huynh, T. (2017). Comprehensible Output: What Students Can Do. Empowering ELLs. Retrieved 2019 from https://www .empoweringells.com/28-comprehensibleoutput/. 
Iwashita, N. (2001). The effect of learner proficiency on interactional moves and modified output in nonnative-nonnative interaction in Japanese as a foreign language. System, 29(2), 267-287. doi: 10.1016/s0346-251x(01)00015-x.

Jazbec, S., Čagran, B., \& Ostir, A.L. (2016). Early Foreign Language Learning from the Children's Perspective. The New Educational Review. 124-136. DOI: 10.15804/tner.2016.45.3.10.

Knežević, S., \& Kovačević, B. (2010). Interactive Learning and Students' Competence in Teaching Literature. Metodički obzori 13, 6(2): 83-92.

Krashen, S. (1981). Second language acquisition and second language learning. Oxford: Pergamon Press.

Krashen, S. (1985). The Input Hypothesis. Harlow: Longman.

Krashen, S. (1998). Comprehensible Output? System 26(2): 175-182.

Kumaravadivelu, B. (2006). TESOL Methods: Changing Tracks, Challenging Trends. TESOL Quarterly, 40(1), 59-81.

Lefstein, A., \& Snell, J. (2011). Classroom Discourse: The Promise and Complexity of Dialogic Practice. In S. Ellis, E. McCartney, \& Bourne, J. (Eds.), Applied Linguistics and Primary School Teaching (pp. 165-185). Cambridge: Cambridge University Press. http://dx.doi.org/10.1017/CBO9780511921605.018.

Long, M.H. (1983). Linguistic and conversational adjustments to nonnative speakers. Studies in Second Language Acquisition, 5, 177-193.

Li, J. (2006). Care for life: School education value orientation. Beijing: Education Science Press.

Lu, X.X., Tang, J.F., \& Luo, X.F. (2007). An Analysis of the Examination-Oriented Education System of China. Journal of Hubei University of Economics. Retrieved 2019 from http://en.cnki.com.cn/Article en/CJFDTOTAL-HBSG200706000.htm.

Lee, J.Y. (2011). English Learning Styles of Students from East Asian Countries: A Focus on Reading Strategies, International Education Studies 4(2); doi:10.5539/ies.v4n2p75.

Lightbown, P.M., \& Spada, N. (2013). How Languages are Learned (Fourth ed.). Oxford: Oxford University Press.

Li, J., Wang, P., \& Chen, Z. (2013). Student developmental needs based parent partnership: A case study of Qilun elementary school in Minhang district, Shanghai. International Journal of Parents in Education, 2, 31-41. 
Li, J. (2015). Student development in everyday classroom life. Fuzhou, China: Fujian Education Press.

Liu, L. (2017). 综合实践活动课程在我国的演变与发展. 小学管理. Retrieved 2020 from http://www.zhsjhdw.com/show.aspx?tid=21\&nid=3563

Lunwen data. (2018).浅谈“以学生为中心”的英语课堂教学. Retrieved 2019 from https://www.lunwendata.com/thesis/2018/148587.html

Mulling, S.S. (1997). Getting Them to Talk: Communicative Activities for the ESOL Classroom. ERIC. Retrieved 2019 from https://files.eric.ed.gov/fulltext/ED409731.pdf

Macaro, E. (1997). Target language, collaborative learning. Oxford: Oxford University Press.

Mackey, A. (1999). Input, interaction and second language development: An empirical study of question formation in ESL. Studies in Second Language Acquisition, 21(4), 557-587.

MEC-Ministry of Education of People's Republic of China. (2001). Guidance on Actively Promoting the English Courses in Primary Schools. Retrieved 2019 from http://old.moe.gov.cn//publicfiles/business/htmlfiles/moe/moe 711/200407/665.ht $\underline{\mathrm{ml}}$.

Ministry of Education. (2001). 基础教育课程改革纲要, [Basic Education Curriculum Reform Outline]. Retrieved 2019 from http://www.moe.edu.cn/ publicfiles/business/htmlfiles/moe/moe 309/200412/4672.html.

MacKenzie, L., \& Ballard, K. (2015). Can Using Individual Online Interactive Activities Enhance Exam Results? MERLOT Journal of Online Learning and Teaching. 11(2): 262-266.

Ministry of Education of People's Republic of China. (2015). 好校长派到薄弱校，信 息化缩小城乡教育差距——徐州取“长”补“短”巧推教育均衡. Retrieved from http://www.moe.gov.cn/s78/A16/s5886/s7822/201603/t20160307_232205.html

Mcintosh, A.J. (2016). Communicative Language Teaching in China. Retrieved from https://www.researchgate.net/publication/289493694_Communicative_Language _Teaching_in_China.

Nunn, B. (2001). Task-based methodology and sociocultural theory. Language TeacherKyoto-JALT, 25(8): 12-20. 
Nuttall, J. (2003). Influences on the Co-construction of the Teacher Role in Early Childhood Curriculum: Some examples from a New Zealand childcare centre. International Journal of Early Years Education, 11(1): 23-31. doi:10.1080/0966976032000066064.

National Bureau of Statistics of China. (2014). China Statistical Yearbook, China Statistics Press, Bejing. Retrieved 2020 from: www.stats.gov.cn/tjsj/ndsj/2014/indexeh.htm.

Nordquist, R. (2017). English as a Foreign Language (EFL) Thoughtco. Retrieved 2020 from: https://www.thoughtco.com/english-as-a-foreign-language-efl-1690597

Nguyen, D.T.T. (2019). Vietnamese Teachers' Perspectives Regarding Task-based Approach to Vocabulary Instruction in Secondary School English as a Foreign Language Classrooms. Unpublished Master's thesis, Florida International University. doi: 10.25148/etd.fidc004086.

OECD. (2016). Education in China: A Snapshot. Paris: Organisation for Economic Co-operation and Development.

Piaget, J. (1970). Science of education and the psychology of the child. New York: Orion Press.

Pica, T., Holliday, L., Lewis, N., \& Morgenthaler, L. (1989). Comprehensible output as an outcome of linguistic demands on the learner. Studies in second language acquisition, 11(1): 63-90.

Pica, T. (1994). Research on negotiation: What does it reveal about second-language learning conditions, processes, and outcomes? Language Learning, 44(3): 493-572.

Prozesky, D.R. (2000). Communication and effective teaching. Retrieved 2020 from https://www.ncbi.nlm.nih.gov/pmc/articles/PMC1705977/.

Pérez-Prado, A. (2019). TESOL teaching methods course. Personal class notes.

Rao, Z. (2002). Chinese students' perceptions of communicative and non-communicative activities in EFL classroom. System, 30(1): 85-105. Retrieved from http://www.sciencedirect.com/science/article/pii/S0346251X01000501>[Accesse d 05 November 2015].

Rao, Z. (2006). Understanding Chinese Students' Use of Language Learning Strategies from Cultural and Educational Perspectives. Journal of Multilingual and Multicultural Development, 27(6): 491-508. 
Roeders, R. (2003): Interaktivna nastava-Dinamika efikasnog učenja i nastava. Beograd: Institut za pedagogiju i andragogiju Filozofskog fakulteta u Beogradu. In Knežević, S.; \& Kovačević, B. (2010). Interactive Learning and Students' Competence in Teaching Literature. Metodički obzori 13, 6(2): 83-92.

Richards, J. C. and Rodgers, T. S., 2014. Approaches and Methods in Language Teaching. 3rd Ed. Cambridge: Cambridge University Press.

Rui, T., \& Chew, P. G. (2013). Pedagogical use of two languages in a Chinese elementary school, Language, Culture and Curriculum, 26(3): 317-331, DOI: 10.1080/07908318.2013.853771.

Swain, M. (1985). Communicative competence: Some roles of comprehensible input and comprehensible output in its development. In Gass, S. and Madden, C. (Eds.), Input in Second Language Acquisition, pp. 235-256. New York: Newbury House.

Salaberri, S. (1995). Classroom language. South Yarra, VIC: Macmillan Education Australia.

Senthamarai, S. (2018). Interactive teaching strategies. Journal of Applied and Advanced Research: 3(1): 36-38.

Sowell, J. (2017). Good Instruction-Giving in the Second-Language Classroom. English Teaching Forum. 55(3): 10-19. Retrieved 2020 from americanenglish.state.gov/english-teaching-forum.

Stevie D. (2018). 3 Exciting Ways the Grammar-translation Method Is Still Great for Language Teaching. Retrieved 2019 from https://www.fluentu.com/blog/educator/grammar-translation-method/\#.

Ur, P. (1996). A course in language teaching: Practice and theory. Cambridge: Cambridge University Press.

Vygotsky, L.S. (1987). Cognition and language. The collected works of L. S. Vygotsky, Vol. 1. Problems of general psychology (R. W. Rieber \& A. S. Carton, Eds.). Plenum Press.

Wolfe, D.E., \& Eugene T.B. (1975). Research on Experiential Learning: Enhancing the Process. Chapter in Buskirk, R.H. (Ed.) Simulation Games and Experiential Learning in Action: 325-336.

Woolfolk, A. (1980). Educational Psychology. London: Pearson.

Wu, X. (2011). 我国小学英语课程与教学改革发展的回顾与反思. Retrieved 2020 from http://www.cnki.com.cn/Article/CJFDTotal-KJJF201104013.htm. 
Wang, Q. (2011). 我国小学英语课程政策与实施分析. Retrieved 2019 from http://www.cnki.com.cn/Article/CJFDTotal-ZGWE201104010.htm.

Watson, A. (2017). 8 Ways Teachers Can Talk Less and Get Kids Talking More. Retrieved 2019 from https://thecornerstoneforteachers.com/8-ways-teachers-cantalk-less-get-kids-talking/.

Waite, S. (2017). Children Learning Outside the Classroom: from Birth to Eleven. Thousand Oaks, CA: SAGE.

Wang, J.J., \& Lin, J. (2018). Traditional Chinese Views on Education as Perceived by International Students in China: International Student Attitudes and Understandings. SAGE Journals. Retrieved 2020 from https://journals.sagepub.com/doi/abs/10.1177/1028315318797356.

Xia, Y., \& Li, C.H. (2012). 教育游戏融入小学英语教学的模式构建. 电化教育研究. Retrieved 2019 from http://www.cnki.com.cn/Article/CJFDTotalDHJY201202023.htm.

Xia, L. (2015). 新教材背景下小学英语有效教学探究——基于部分小学英语故事案 例的分析. 英语广场, 54: 154-155.

Ye, L. (1994). The Spirit of the Times and the Developing of a New Educational Ideal. Education Research, 10, 3-8.

Ye, L. (2006). On “New Basic Education.” Beijing: Education Science Press.

Yee, K. (2019). Interactive Techniques. Creative Commons BY-NC-SA Retrieved 2019 from https://www.usf.edu/atle/documents/handout-interactive-techniques.pdf

Yu, Y. (2008). 中国英语教学现状的回顾与思考. 辽宁农业职业技术学院报. 4. Retrieved 2019 from http://www.cnki.com.cn/Article/CJFDTotalLNNJ200804031.htm.

Zheng,Z. (2011). 城乡小学英语课堂教学的对比研究. Retrieved 2019 from http://cdmd.cnki.com.cn/Article/CDMD-10445-1011080648.htm

Zhou, L.J., \& Zhang, X. Q. (2011). 西部农村小学英语教师培训问题及对策探讨. Retrieved 2019 from http://www.cnki.com.cn/Article/CJFDTotalKJJF201102020.htm.

Zhang, D.B. (2012). Chinese Primary School English Curriculum Reform. Chapter in Ruan, J. \& Leung, C (Ed.) Perspectives on Teaching and Learning English Literacy in China, pp. 67-83. New York: Springer. 
Zhang, D.Y., Li, Y.X., \& Wang, Y.F. (2013). How Culturally Appropriate Is the Communicative Approach with Reference to the Chinese Context? Creative Education, 4(10): 1-5.

Zha, Q. (2015). The Good, Bad, and Ugly Dimensions of Chinese Education. The World View. Retrieved 2020 from https://www.insidehighered.com/blogs/worldview/good-bad-and-ugly-dimensions-chinese-education.

Zhou, Y. (2018). 从“三阶段”“四方面”透析国内小学英语教学现状研究. 读与写, 15(6): 73-131. DOI:10.16071. 


\section{APPENDIX A}

\section{Support Letters}

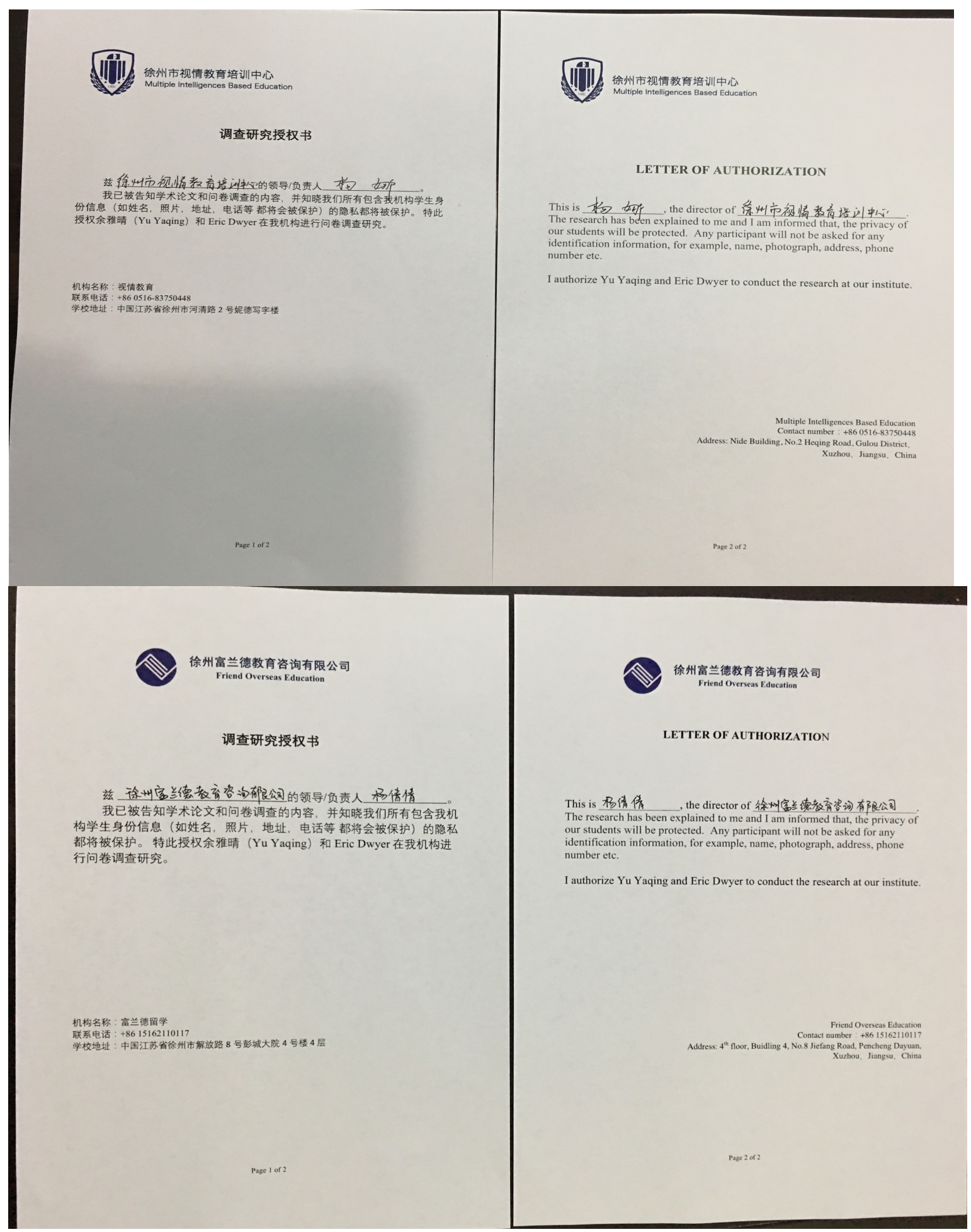




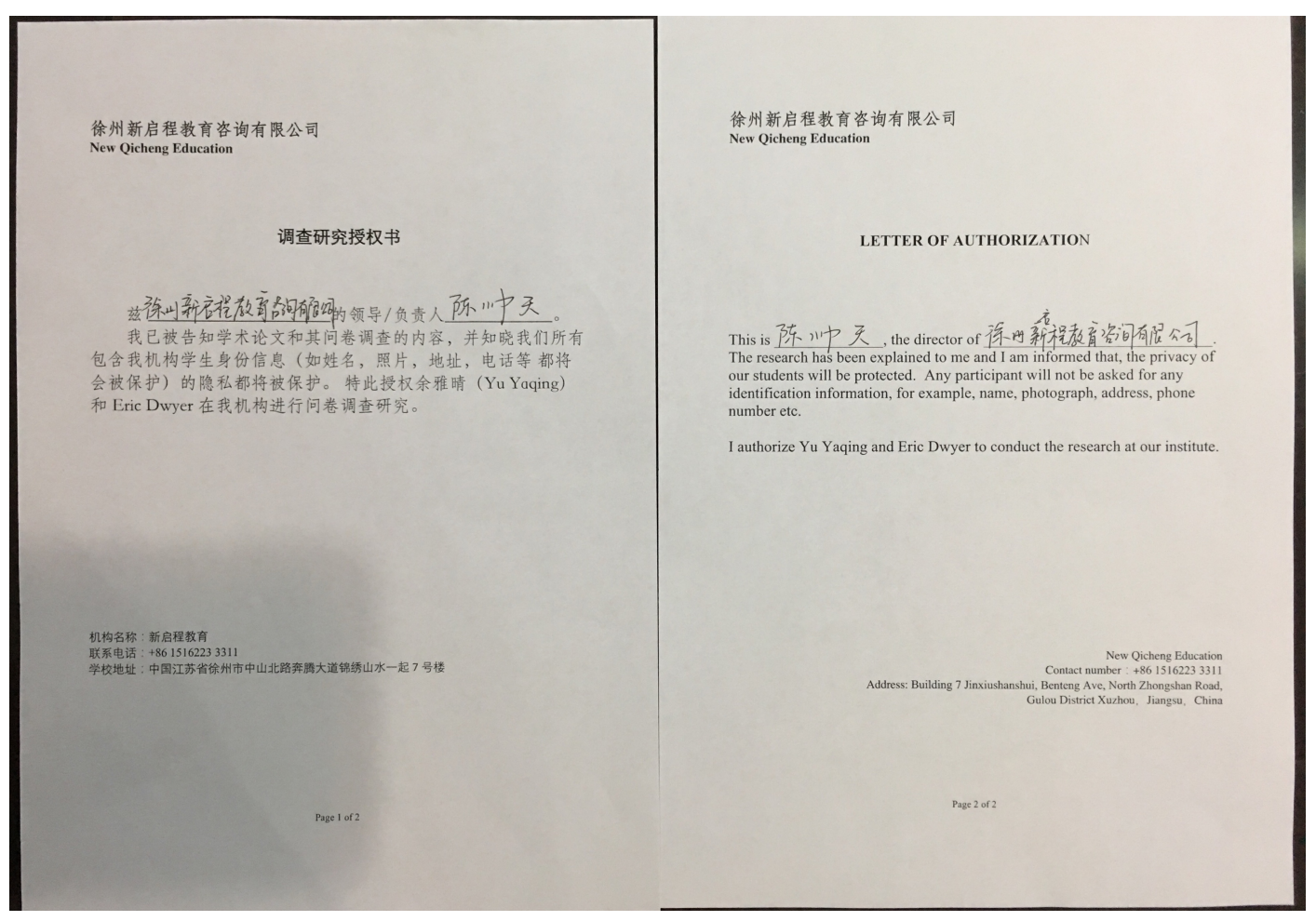




\title{
APPENDIX B
}

\author{
Consent forms
}

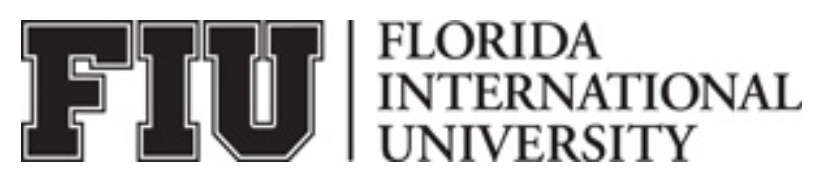

\section{PARENTAL CONSENT TO PARTICIPATE IN A RESEARCH STUDY Elementary School Children's Perspectives of Interactive Activities in English Classrooms in China}

\section{SUMMARY INFORMATION}

- Purpose: The purpose of the study is to discover students' understanding and achievement of the ESL interactive activities.

- Procedures: If you choose to allow your child to participate, your child will be asked to see pictures of classroom activities and fill the blanks in a questionnaire with a children reading-friendly form.

- Duration: This will take about 10 to 15 minutes.

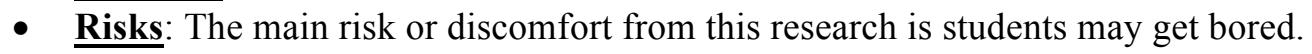

- Benefits: The main benefit to your child from this research is to learn from the survey.

- Alternatives: There are no known alternatives available to your child other than not taking part in this study.

- Participation: Taking part in this research project is voluntary.

Please carefully read the entire document before agreeing to participate.

\section{PURPOSE OF THE STUDY}

The purpose of this study is to discover students' understanding and achievement of the ESL interactive activities. Students' understanding includes their value, motivation, participation, their attitudes towards teachers' instruction and revision, and their expectation of the teaching forms and tools. The achievement consists of an assessment of interactive activities and students' academic and social development.

\section{NUMBER OF STUDY PARTICIPANTS}

If you agree to allow your child to participate in this study, he/she will be one of 100 people in this research study.

\section{DURATION OF THE STUDY}

\section{PROCEDURES}

If your child participates in this study, we will ask your child to do the following things:

1. Watch pictures of interactive activities in English classrooms.

2. We will ask whether your child has experienced the same or similar situation in the pictures.

3. If the answer is yes, your child will receive a questionnaire.

4. The content of the questionnaire is to find out your child's attitude and understanding of the interactive activities, and your child's achievement or complaints from the interactive activities. Your child will be asked to fill the questionnaire according to his/her real experience. 


\section{RISKS AND/OR DISCOMFORTS}

The study has the following possible risks to your child:

The only risk your child may experience is getting a little bored while filling the blanks on the questionnaire.

\section{BENEFITS}

The study has the following possible benefits to your child:

They can learn from the questionnaire. Their ability of critical thinking may be cultivated.

\section{ALTERNATIVES}

There are no known alternatives available to your child other than not taking part in this study. Any significant new findings developed during the course of the research which may relate to your child's willingness to continue participation will be provided to you.

\section{CONFIDENTIALITY}

The records of this study will be kept private and will be protected to the fullest extent provided by law. In any sort of report we might publish, we will not include any information that will make it possible to identify your child. Research records will be stored securely, and only the researcher team will have access to the records. However, your child's records may be inspected by the authorized university (FIU) or other agents, who will also keep the information confidential.

\section{USE OF YOUR CHILD'S INFORMATION}

Your child's information collected as part of the research will not be used or distributed for future research studies even if identifiers are removed.

\section{COMPENSATION \& COSTS}

Your child will not receive a payment for your participation. There are no costs to your child for participating in this study.

\section{RIGHT TO DECLINE OR WITHDRAW}

Your child's participation in this study is voluntary. Your child is free to participate in the study or withdraw his/her consent at any time during the study. Your child will not lose any benefits if he/she decides to not participate or if your child quits the study early. The investigator reserves the right to remove your child from the study without your consent at such time that he/she feels it is in their best interest.

\section{RESEARCHER CONTACT INFORMATION}

If you have any questions about the purpose, procedures, or any other issues relating to this research study, you may contact Yaqing Yu at 3760 Bird Road, Miami, Florida USA, +1 786906-5469, sara317810@gotmail.com.

\section{IRB CONTACT INFORMATION}

If you would like to talk with someone about your child's rights of being a subject in this research study or about ethical issues with this research study, you may contact the FIU Office of Research Integrity by phone at 305-348-2494 or by email at ori@fiu.edu.

\section{PARTICIPANT AGREEMENT}

I have read the information in this consent form and agree to allow my child to participate in this study. I have had a chance to ask any questions I have about this study, and they have been answered for me. I understand that I will be given a copy of this form for my records. 
Printed Name of Parent/ Guardian

Printed Name of Child Participant

Signature of Person Obtaining Consent

Date

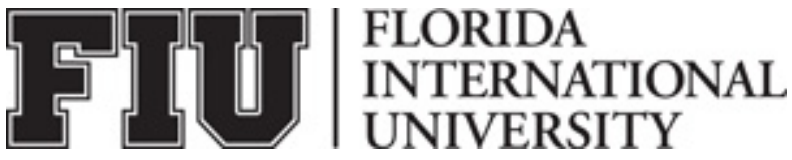

\section{CHILD ASSENT TO PARTICIPATE IN A RESEARCH STUDY Elementary School Children's Perspectives of Interactive Activities in English Classrooms in China}

\section{WHY ARE YOU DOING THIS STUDY?}

We would like for you to be in a research study we are doing. A research study is a way to learn information about something. We would like to find out more about how you like interactive activities while learning English, and what you achieve from interactive activities when learning English.

\section{HOW MANY OTHERS WILL BE IN THIS STUDY?}

If you agree to participate in this study, you will be one of 100 children in this research study.

\section{WHAT WILL HAPPEN IN THIS STUDY?}

If you participate in this study, we will ask you to do the following things:

5. Watch pictures of interactive activities in English classrooms

6. We will ask whether you have experienced the same or similar situation in the pictures.

7. If your answer is yes, you will receive a questionnaire.

8. The content of the questionnaire is to find out your attitude and understanding of the interactive activities, and your achievement or complaints from the interactive activities.

You will be asked to fill the questionnaire according to your true situation.

HOW LONG WILL THE STUDY LAST?

Your participation will require 10 to 15 minutes. 


\section{CAN ANYTHING BAD HAPPEN TO ME?}

Some things may make you uncomfortable such as, you may get bored in these 10 to 15 minutes while filling the blanks.

\section{CAN ANYTHING GOOD HAPPEN TO ME?}

The following benefits may be associated with your participation in this study:

You may also learn from the questionnaire and pictures to find your way to learn English, or you may find your motivation to learn English.

\section{DO I HAVE OTHER CHOICES?}

There are no known alternatives available to you other than not taking part in this study.

\section{WILL ANYONE KNOW I AM IN THE STUDY?}

The records of this study will be kept private and will be protected by the researchers.

\section{WILL I BE GIVEN ANYTHING FOR PARTICIPATING?}

You will not receive a payment for your participation.

\section{WHAT IF I DO NOT WANT TO DO THIS?}

You do not have to be in this study if you don't want to, and you can quit the study at any time. If you don't like a question, you don't have to answer it and, if you ask, your answers will not be used in the study. No one will get mad at you if you decide you don't want to participate.

\section{WHO CAN I TALK TO ABOUT THE STUDY?}

If you have any questions about the research study, you may contact Yaqing Yu at 3760 Bird Road, Miami, Florida US, +1786-906-5469 +86 15852178877, sara317810@gotmail.com. If you would like to talk with someone about your rights of being a participant in this research study, you may contact the FIU Office of Research Integrity by phone at 305-348-2494 or by email at ori@,fiu.edu.

\section{PARTICIPANT AGREEMENT}

This research study has been explained to me and I agree to be in this study.

Signature of Child Participant

Printed Name of Child Participant

\footnotetext{
Signature of Person Obtaining Consent
}

\section{Date}




\section{APPENDIX C}

\section{Flyer}

My dear little fellow,

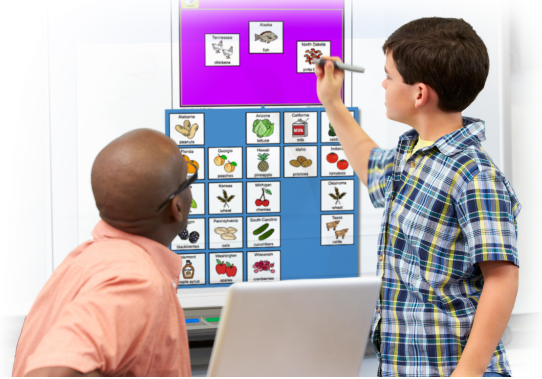

No matter you like English or not, no matter whether you had fun learning experience in English class. If you ever participated in interactive learning activity in your English class, we would love to know how you were influenced by those activities. would you like to take an opportunity to create your critical thinking, make your voice heard, meanwhile contribute to improve the quality of English teaching in Chinese elementary school?

We guarantee that, your privacy is privileged. Any participant will not be asked for any identification information, for example, name, photograph, address, phone number etc. The calculation for each submitted form will be only through a randomly generated code number.

Appreciate for your help!

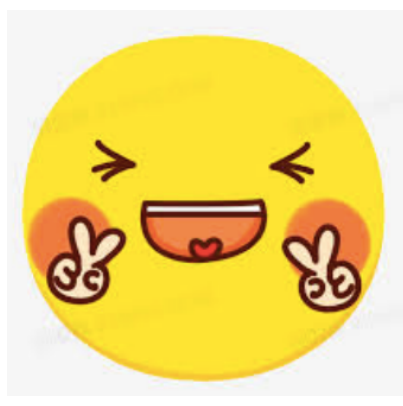




\section{APPENDIX D}

\section{Back Translations-Parental Consent}

\section{FLORIDA INTERNATIONAL UNIVERSITY \\ GUARDIAN/PARENT'S CONSENT TO PARTICIPATE IN A RESEARCH STUDY \\ Elementary School Children's Perspectives of Interactive Activities in English Classrooms in China}

\footnotetext{
Summary:

- Purpose: The purpose of this study is to find out students' understanding and achievement of interactive English teaching activities.

- Procedures: If you choose to allow your child to participate, your child will be asked to watch classroom teaching pictures and fill in a questionnaire which is easy for children to understand.

- Duration: It will take about 10 to 15 minutes.

- Risks: The main risk or discomfort of this study is that students may feel bored in filling out questionnaires.

- Benefits: The main benefit of this study for your child is that your child will learn more knowledges from this survey.

- $\quad$ Alternatives: Your child has no known alternatives other than not participating in this study.

Participation: This is voluntary participation

Please carefully read the whole document before agreeing to participate.
}

\section{Research purposes:}

The purpose of this study is to find out students' understanding of interactive English teaching activities and their achievements. Students' understanding includes: values, motivation, participation, attitudes towards teachers' teaching and revision, expectations of teaching forms and teaching tools. Its achievements include the evaluation of interactive English teaching activities, students' academic achievements and social development.

\section{Number of participants:}

About 100 people will participate in this questionnaire. If you agree with your child to participate in the questionnaire, he or she will be one of them.

Duration of the study:

We will take your child 10-15 minutes to complete the questionnaire.

\section{Research process:}

If your child is involved in the study, here are the steps:

1. Your child will see some pictures which will be related to interactive English teaching activities.

2. He or she will be asked whether he or she participates in such activities in English class, and whether he or she has played games in English class. 
3. If your child answers yes, he or she will receive a questionnaire.

4. The content of this questionnaire is about your child's attitude and understanding of interactive English teaching activities, and the achievements or troubles that interactive English teaching activities bring to him or her. Your child will be asked to answer truthfully according to his or her real situation.

\section{Risk or discomfort:}

This project study will not affect your child's physical and mental health. The only problem they may encounter is that they may feel a little bored when filling out the questionnaire.

\section{Benefits:}

Your child can learn from questionnaires. Their critical thinking ability can be cultivated.

\section{Options:}

Your child has no known alternatives other than not participating in this study. In the course of this study, any important new findings related to your child's willingness to continue participating will be provided to you.

\section{Confidentiality:}

The records of this study will be kept confidential and protected to the maximum extent prescribed by law. In any type of report we may publish, we will not contain any information that will enable your child to be identified. Research records will be stored securely, and only research teams can access them. However, your child's records may be viewed by authorized universities or other agents which will also keep the information confidential.

\section{Information to use:}

The collected information from your child in this study will not be used or distributed for future research even though the identifiers are removed.

\section{Compensation and costs:}

Your child will not receive payment for your participation. There are also no costs to your child for participating in this study.

\section{Rights and Interests: Refusal and Withdrawal}

Your child is a volunteer for the study. Your child is free to participate or opt out at any time during the study. If your child decides not to participate or quit early, your child will not lose any benefits. Investigators will hold the right to remove your child's involvement from the project without your consent.

\section{Researcher contact information:}

If you have any questions about the purpose, process and management of the survey, please contact the researchers through the following ways: 
Name: Yaqing Yu

Address: 3760 Bird Road, Miami, Florida US,

Tel: +1786-906-5469, +86 15852178877

E-mail: sara317810@hotmail.com.

IRB contact information:

You can also contact the Research Integrity Office of the Florida International University to learn about your child's rights or ethical issues when participating in dispatch research.

Tel: +1 305-348-2494 e-mail: ori@fiu.edu.

\section{Participant agreements:}

I have read the information in this Agreement and agreed to allow my children to participate in the study. I have had the opportunity to ask any questions about this study, and they have answered for me. I know I will receive a copy of this form for archiving.

Signature of Parent/Guardian

Printed Name of Parent/ Guardian

Printed Name of Child Participant

Signature of Person Obtaining Consent $\overline{\text { Date }}$

Date 


\section{Back Translations-Children's Consent}

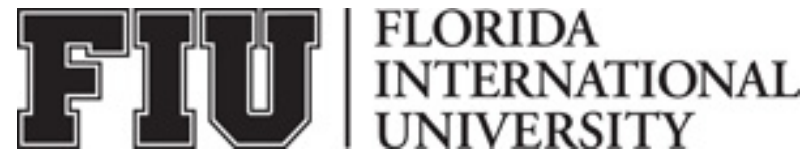

\section{CHILD ASSENT TO PARTICIPATE IN A RESEARCH STUDY Elementary School Children's Perspectives of Interactive Activities in English Classrooms in China}

\section{Why are you involved in this research?}

We wish you can take part in a research what we are conducting. We want to know more about how you view interactive activities in learning English and how interactive activities can help you learn English.

How many people were involved in the study?

About 100 people will participate in this study, and you will be one of them.

What is the research process?

If you are involved in this study, here are the steps:

1. You will see some pictures related to interactive English teaching activities.

2. You will be asked whether you have participated in such activities in English classes, and whether you have ever played interactive games in English classes and so on.

3. If your answer is yes, you will receive a questionnaire.

4. The content of this questionnaire is about your attitude and understanding of interactive English teaching activities, and the achievements or troubles that interactive English teaching activities bring to you. You need to answer truthfully according to your real situation.

How long is the study?

10-15 minutes

Will there be any adverse consequences if I take part in the research?

There will be no adverse consequences. If there are any, you may feel a little bored when filling out the questionnaire.

Will my participation in research benefit me?

The benefit that this questionnaire may bring to you is that you will acquire some knowledge, because the process of answering questions is also the process of learning. You may find your motivation to learn English from the questionnaire.

Do I have any other choice?

If you don't want to participate in the questionnaire, you don't have to. You can quit anytime.

Will anyone else know about my involvement in the research?

Please rest assured that your answers and information are strictly confidential. 
Will my participation in research be rewarded?

Unable. There is no financial support for this survey. You will not be paid in this research study. Thank you very much for your voluntary participation.

What if I don't want to participate in research?

In the process of participating in the research, if any questions make you feel uncomfortable, you can quit at any time, and your previous answers will not be included in the final statistics. No one will blame you of giving up halfway.

\section{Researcher contact information:}

If you have any questions about the purpose, process and management of the survey, please contact the researchers through the following ways:

Name: Yaqing Yu

Address: 3760 Bird Road, Miami, Florida US,

Tel: +1786-906-5469, +86 15852178877

E-mail: sara317810@hotmail.com.

IRB contact information:

You can also contact the Research Integrity Office of the Florida International University to learn about your child's rights or ethical issues when participating in dispatch research.

Tel: +1 305-348-2494 e-mail: ori@fiu.edu.

\section{PARTICIPANT AGREEMENT}

This research study has been explained to me and I agree to be in this study.

Signature of Child Participant

Date

Printed Name of Child Participant

Signature of Person Obtaining Consent

Date 


\section{Back Translation-Questionnaire}

- I am a $\quad$ I'm in grade__(Boy/girl)
- I am___years old

\begin{tabular}{|c|c|c|c|c|c|c|c|}
\hline Theme & Category & Question & 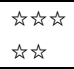 & 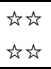 & 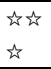 & is & 放 \\
\hline \multirow{22}{*}{$\begin{array}{l}\text { Understanding } \\
\text { of the English } \\
\text { interactive } \\
\text { activities }\end{array}$} & \multirow[t]{3}{*}{ Motivation } & $\begin{array}{l}\text { I like to participate in the interactive activities because I } \\
\text { can learn happily }\end{array}$ & & & & & \\
\hline & & $\begin{array}{l}\text { I expect to do the interactive activities because it's time } \\
\text { consuming }\end{array}$ & & & & & \\
\hline & & $\begin{array}{l}\text { I don't care about the interactive activity. I just do what } \\
\text { the teacher says }\end{array}$ & & & & & \\
\hline & \multirow{5}{*}{$\begin{array}{l}\text { View \& } \\
\text { Value }\end{array}$} & I like the interactive activities & & & & & \\
\hline & & I think interactive activities is important in class & & & & & \\
\hline & & I think interactive activities helps me learn & & & & & \\
\hline & & I wish I can do well in interactive activities & & & & & \\
\hline & & $\begin{array}{l}\text { I don't like the interactive activities because it's such a } \\
\text { waste of time }\end{array}$ & & & & & \\
\hline & \multirow[t]{4}{*}{ Participation } & $\begin{array}{l}\text { I am eager to participate in interactive English teaching } \\
\text { activities }\end{array}$ & & & & & \\
\hline & & $\begin{array}{l}\text { I can totally immerse myself in Interactive English } \\
\text { teaching activities. }\end{array}$ & & & & & \\
\hline & & $\begin{array}{l}\text { I hope that the whole English class will be interactive } \\
\text { teaching activities. }\end{array}$ & & & & & \\
\hline & & $\begin{array}{l}\text { I hope that interactive teaching activities can be } \\
\text { interspersed in English class. }\end{array}$ & & & & & \\
\hline & \multirow[t]{5}{*}{ Instruction } & $\begin{array}{l}\text { I hope teachers can use Chinese to explain interactive } \\
\text { English teaching activities. }\end{array}$ & & & & & \\
\hline & & $\begin{array}{l}\text { I hope that teachers will use English to explain } \\
\text { interactive English teaching activities. }\end{array}$ & & & & & \\
\hline & & $\begin{array}{l}\text { I hope teachers can use Chinese and English to explain } \\
\text { interactive English teaching activities. }\end{array}$ & & & & & \\
\hline & & $\begin{array}{l}\text { I can understand the activity requirements if the teacher } \\
\text { uses a lot of body language to cooperate with the } \\
\text { English explanation. }\end{array}$ & & & & & \\
\hline & & $\begin{array}{l}\text { I can understand the activity requirements if the teacher } \\
\text { uses a lot of body language to cooperate with the } \\
\text { English explanation and give examples. }\end{array}$ & & & & & \\
\hline & \multirow[t]{2}{*}{ Revision } & $\begin{array}{l}\text { Teachers can solve problems and situations in activities } \\
\text { very well. }\end{array}$ & & & & & \\
\hline & & $\begin{array}{l}\text { Teachers often ask us to discuss the harvest of the } \\
\text { activities and give us suggestions after the activities. }\end{array}$ & & & & & \\
\hline & \multirow[t]{3}{*}{ Forms } & I like interactive English teaching activities with music. & & & & & \\
\hline & & $\begin{array}{l}\text { I like interactive English teaching activities with } \\
\text { pictures and videos. }\end{array}$ & & & & & \\
\hline & & $\begin{array}{l}\text { I like interactive English teaching activities with } \\
\text { competitions and awards. }\end{array}$ & & & & & \\
\hline \multirow{8}{*}{$\begin{array}{l}\text { Achievements } \\
\text { of the English } \\
\text { interactive } \\
\text { activities }\end{array}$} & \multirow{7}{*}{$\begin{array}{l}\text { General } \\
\text { Assessment }\end{array}$} & I am quite satisfied with the interactive activities & & & & & \\
\hline & & $\begin{array}{l}\text { Teachers are satisfied with our performance in } \\
\text { interactive English teaching activities. }\end{array}$ & & & & & \\
\hline & & $\begin{array}{l}\text { I don't think I learned anything in the interactive } \\
\text { English teaching activities. }\end{array}$ & & & & & \\
\hline & & $\begin{array}{l}\text { I often heard complaints from my classmates about } \\
\text { interactive English teaching activities. }\end{array}$ & & & & & \\
\hline & & $\begin{array}{l}\text { I can remember the language point after the interactive } \\
\text { activities }\end{array}$ & & & & & \\
\hline & & $\begin{array}{l}\text { I learned what I suppose to learn through the interactive } \\
\text { activities }\end{array}$ & & & & & \\
\hline & & I learned nothing from the interactive activities & & & & & \\
\hline & $\begin{array}{l}\text { Academic } \\
\text { Outcome }\end{array}$ & $\begin{array}{l}\text { I do well in the interactive activities and I get a good } \\
\text { test score }\end{array}$ & & & & & \\
\hline
\end{tabular}




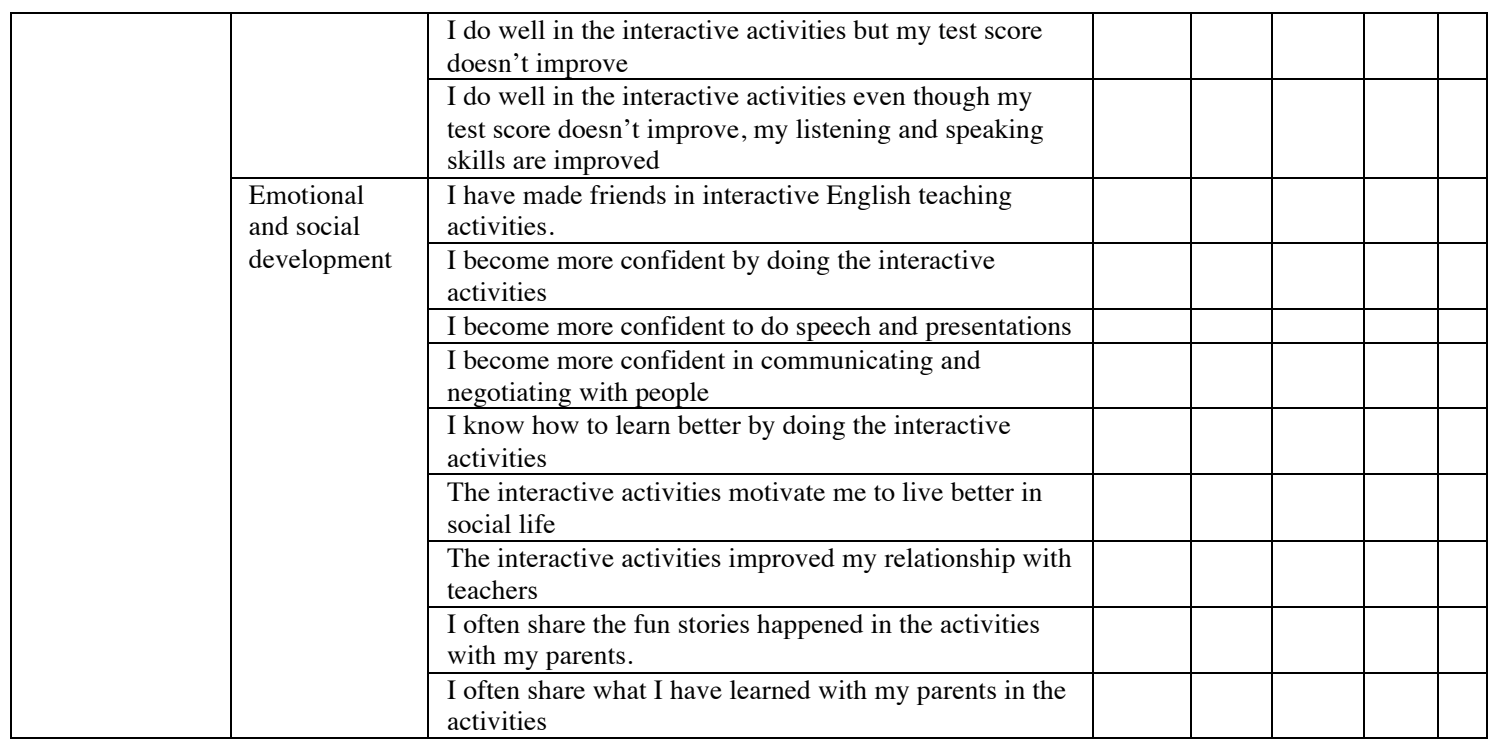

\section{Remark:}

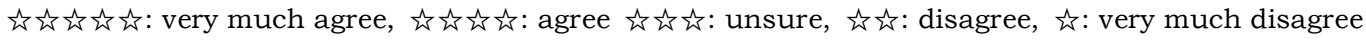

